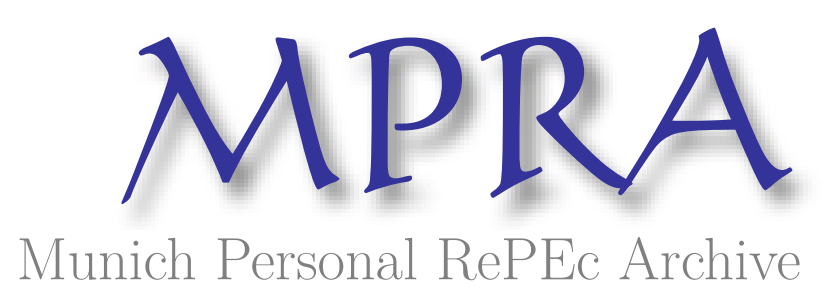

\title{
Extent of Exchange Rate Coordination in Asia
}

Sen Gupta, Abhijit

India Resident Mission, Asian Development Bank

2015

Online at https://mpra.ub.uni-muenchen.de/66636/

MPRA Paper No. 66636, posted 23 Sep 2015 04:47 UTC 


\title{
Extent of Exchange Rate Coordination in Asia
}

Abhijit Sen Gupta*

\begin{abstract}
High level of intra-regional trade and negative spillovers from competitive devaluation make exchange rate coordination extremely desirable in Asia. Employing a hypothetical Asian Currency Unit we evaluate the degree of coordination among Asian currencies. Traditional empirical tests yield little evidence of coordination among real and nominal exchange rates. However, introducing endogenously determined structural breaks to account for changes in exchange rate regimes provides more mixed evidence. While there is still little evidence for coordination in nominal terms, some degree of coordination among real rates emerges. The limited evidence for exchange rate coordination can be explained by the diverse exchange rate regimes prevailing in these economies, signaling differences in policy objectives.
\end{abstract}

Keywords: Asian Currency Unit, currency coordination, structural breaks, exchange rate regimes, panel unit root

JEL Classification: F33; F36; N15 and E58

\footnotetext{
Economist, India Resident Mission, Asian Development Bank Email: asengupta@adb.org

The views expressed in this paper are those of the authors and do not necessarily reflect the views and policies of Asian Development Bank (ADB) or its Board of Governors or the government they represent.
} 


\section{Introduction}

Economic integration in Asia has evolved in a significantly different manner than it did in Europe. In Europe, economic integration was driven primarily by a top down approach through coordinated initiatives and the creation of regional institutions with the objective of creating a united front across various countries. In contrast, in Asia, market forces have driven economic integration. Over the past few decades, East Asia has become increasingly intertwined economically as the share of interregional trade in total trade has increased sharply across most economies, driven by regional supply chains and production networks. These production networks, created through individual firms' decisions on location of business, sourcing of parts and raw materials, destination of the final product, and hiring of workers, have led to a rise in intraregional trade and investment reflecting intra-industry processing and assembly through vertically integrated production.

IMF (2007) shows that while trade flows in the rest of the world increased by 3 times between 1990 and 2006, in emerging Asia, inter-regional trade rose by 5 times, and intraregional trade increased by 8.5 times. A supportive economic policy initiated by Asian governments to open up the economy, attract investment, and promote exports has hastened the integration. The trade and investment nexus has been greatly enhanced by the pursuit of the flying geese pattern, and this has played an important role in fostering growth in

the

region.

The high degree of economic integration postulates a strong case for exchange rate coordination, as exchange rate misalignments may result in loss of competitiveness for a country, possibly leading to an increase in protectionism, which in turn could promote a round of beggar-thy-neighbor devaluations. Large swings in bilateral exchange rates could also influence decisions about the location of new and existing investments. In contrast, greater stability in exchange rates would support investment by increasing price transparency and reducing currency-related hedging costs for companies. Finally, sharp exchange rate movements in one currency could affect another country's ability to maintain a particular exchange rate regime.

Despite the strong case for exchange rate coordination, such coordination continues to be a long-drawn process at the best of times, involving intensive policy dialogue. The creation of the euro was a culmination of more than two decades of deliberations among the member countries. Coming out of the Asian crisis, many pushed for the replication of the euro experiment in Asia. However, the heterogeneity of the Asian countries in terms of their institutional capability and policy frameworks will add to the difficulty of exchange rate coordination, which is already long and arduous. Consequently, while a convergence on the eurozone model is not possible in the foreseeable future in Asia, it is possible to move towards the creation of a "parallel currency" as suggested by Eichengreen (2006). The parallel currency could circulate alongside national currencies.

As pointed out in studies like Kawai and Takagi (2005), Ogawa and Shimizu (2007) and Girardin and Steinherr (2008), a strong contender for the parallel currency is an Asian Currency Unit, which would be a basket of appropriately weighted regional currencies. An ACU would allow transactions such as exports, imports, lending, deposit taking and issuing bonds to be denominated in a more stable currency, thereby facilitating exchange rate coordination through market forces rather than political pressures. Kuroda and Kawai (2002) also point out that such a basket would help to monitor the collective movement of the participating currencies against external currencies as well as the movement of the individual

\footnotetext{
${ }^{1}$ The flying geese paradigm, based on global division of labor on the basis of dynamic comparative advantage, argues that the Asian economies will converge to the advanced Western economies through a process of regional hierarchy with production of goods shifting from the more advanced countries to the less advanced ones.
} 
currencies compared to the regional benchmark. The recent global financial crisis emphasized the need for greater diversification out of the US dollar as an international reserve currency. With countries denominating transactions in ACU, central banks could hold part of their portfolio in the regional benchmark, thereby reducing their overwhelming dependence on the US dollar.

\section{Evidence of Exchange Rate Coordination using An Asian Currency Unit}

\subsection{Proposing an Asian Currency Unit}

A key issue in the formulation of an ACU is the inclusion of participating currencies. The participating currencies have varied across different studies. Most of the studies such as Ogawa and Shimizu (2005), Ogawa and Yoshimi (2008) and Wyplosz (2010) have focused on the currencies of the ASEAN+3 countries. In this paper we expand the set of participating countries to include Hong Kong, China; and India. Hong Kong, China has already established close trade and financial links with other East Asian economies, especially the PRC. Furthermore it has been a part of a number of regional initiatives like the Executives Meeting of East Asia Pacific Central Banks (EMEAP) and the Chiang Mai Initiative Multilateralization (CMIM). In contrast, India is still not a member of these initiatives and is not as closely linked to the East Asian economies. However, given that the process of exchange rate coordination is a long process, there is a need to have a dynamic outlook for the region. At its current growth rate, India is expected to be among the top three economies of the region during the next three decades. Furthermore, in recent years India has sought to increase its trade and financial links with other Asian economies. According to the International Monetary Funds (IMF) Direction of Trade Statistics, Indian exports to the region increased from $19 \%$ in 2001 to $26.3 \%$ in 2011 while imports increased from $18.2 \%$ to $27.7 \%$. Trade links are likely to further increase given that India has signed or is negotiating trade agreements with ASEAN, Indonesia, Japan, Malaysia, Singapore, and Thailand. Similarly, several Asian economies including Japan, Korea, and Singapore have invested in India's infrastructure, automobiles, electronics, financial, pharmaceutical, logistics, and information technology sectors.

Table 1: Weights Accorded to Participating Currencies in the Asian Currency Unit

\begin{tabular}{|l|c|}
\hline Country & Average Weights \\
\hline Brunei Darussalam & $0.12 \%$ \\
Cambodia & $0.10 \%$ \\
PRC & $27.98 \%$ \\
Hong Kong, China & $11.33 \%$ \\
India & $8.49 \%$ \\
Indonesia & $3.82 \%$ \\
Japan & $23.15 \%$ \\
Republic of Korea & $8.82 \%$ \\
Lao PDR & $0.06 \%$ \\
Malaysia & $4.82 \%$ \\
Myanmar & $0.24 \%$ \\
Philippines & $1.37 \%$ \\
Singapore & $5.01 \%$ \\
Thailand & $3.53 \%$ \\
Viet Nam & $1.19 \%$ \\
\hline
\end{tabular}

Lao PDR = Lao Peoples Democratic Republic; PRC = Peoples Republic of China.

Notes: The weights are based on the average between 2004 and 2007.

Sources: World Development Indicators; IMFs Direction of Trade Statistics and Coordinated 
Next, we have to assign weights to the various participating currencies. The choice of the economic indicators in assigning weights needs to reflect both the current and the potential size of the economy, and the extent to which the country will use the ACU. Thus weights assigned are based on the average of the individual country's share in the regional gross domestic product (GDP) measured at purchasing power parity, intraregional trade, and intraregional investment. While GDP measured at purchasing power parity is an indicator of the potential size of the economy, trade and investment based weights provide an indication about the extent to which participating currencies could employ the ACU. Table 1 highlights the weights accorded to the 15 economies, which is calculated as the average of shares of these economies GDP based on purchasing power parity, intraregional trade, and investment.

In order to evaluate the collective movement of the participating currencies against the numèraire currency and the relative movement of these currencies against the ACU we need to identify a base period. The base period is chosen as a year when the deviations among the important macroeconomic indicators are least. The rationale is that members of a common currency area need to follow a coherent set of domestic policies for the common currency area to be stable. The Maastricht convergence criteria for joining the European Economic and Monetary Union were established precisely for the purpose of ensuring coherent policymaking. It focused on convergence of government deficits, government debt, inflation rates, exchange rates, and long-term interest rates. To analyze external and internal stability we focus on these indicators as well as current account deficits and find that the divergence among these indicators was least in 2000 and 2001, and take them as the base period. This is in line with other studies such as Ogawa and Shimizu (2005) and Ogawa and Taiyo (2009).

The United States continues to be the dominant trade partner outside the region for most of the economies. The countries of the Eurozone are the other major trading partners. Consequently, we include both the US dollar and the euro in the numèraire currency basket. Based on their trade shares between 2004 and 2007 the currency basket is made up of $60 \%$ of the US dollar and $40 \%$ of euro. It is assumed that 1 unit of the ACU is equivalent to 1 unit of the numèraire currency basket in the base period. Briefly, the value of the Asian Currency Unit in terms of the numèraire currency basket is given as

$$
\varepsilon_{A C U, t}^{N u m}=\sum_{i} \omega_{i} \varepsilon_{i, t}^{N u m}
$$

where $\varepsilon_{A C U, t}^{N u m}$ is the value of the ACU in terms of the numèraire basket at time $t, \omega_{i}$ is the weight of currency $\mathrm{i}$ based on Table 1 and $\varepsilon_{i, t}^{N u m}$ is the value of currency $\mathrm{i}$ relative to the currency basket at time t.

Figure 1 shows that the ACU appreciated by about 10\% between 2001 and 2011 . However, the ACU did not strengthen in a monotonic manner. There was a decline in the value of the ACU vis-à-vis the numèraire basket by about $10 \%$ between 2001 and mid-2003. This was largely due to the weakening of the Japanese Yen and the Chinese Yuan, which have a combined weight of nearly $50 \%$ in the ACU. The ACU was relatively stable between mid2003 and late 2006. Most Asian currencies were relatively stable vis-à-vis the numèraire basket during this period. The only exceptions were the Indonesian Rupiah, which weakened by $12 \%$ and the Korean Won, which strengthened by $18.5 \%$. 


\section{Figure 1: Movement of the Asian Currency Unit vis-à-vis the Numèraire Basket}

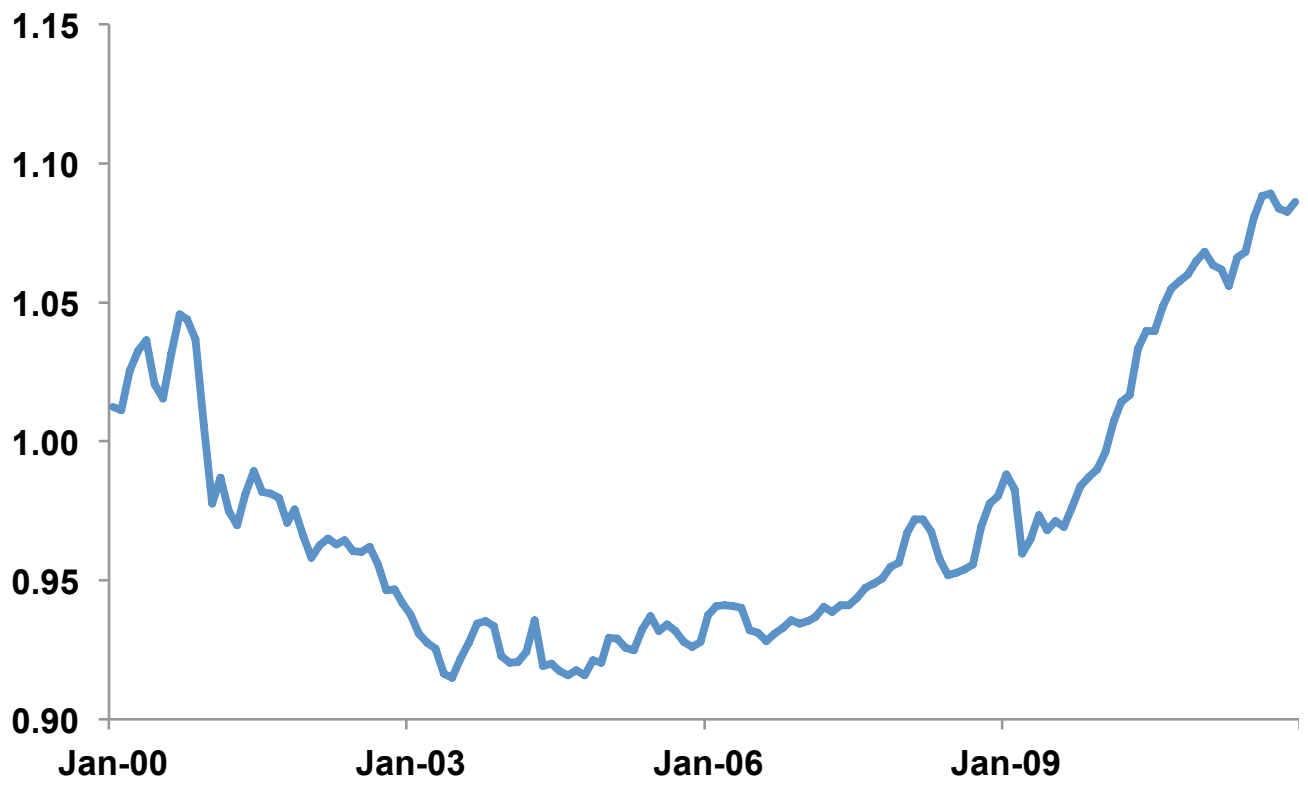

Since late 2006, the ACU strengthened by $17 \%$ against the numèraire basket. During this period the yen appreciated against the euro by $39 \%$ and against the US dollar by $51 \%$. The yuan, which had abandoned the tight peg in July 2005, also appreciated by $24 \%$ against the US dollar between September 2006 and 2011. Other Asian currencies, which experienced significant strengthening against the numèraire basket, include the Singapore Dollar, the Thai Baht, and the Malaysian Ringgit. The Brunei Dollar, by virtue of the currency board arrangement with Singapore Dollar, and the Lao Kip also appreciated during this period. On the other hand, currencies that became weaker over this period include the Korean Won, Indian Rupee and Vietnamese Dong.

\subsection{Deviation from the Asian Currency Unit}

A regional currency unit would also help to monitor the movement of the participating currencies against the regional benchmark and analyze the co-movement of the participating currencies. To monitor the movement of the participating currencies we use the following arbitrage condition

$$
\varepsilon_{i, t}^{A C U}=\varepsilon_{i, t}^{N u m} \varepsilon_{N u m, t}^{A C U}
$$

The value of a participating currency in terms of the ACU is a product of the bilateral exchange rate between the currency and numèraire basket and the value of the numèraire basket in terms of the ACU. Following Ogawa and Shimizu (2005), we look at the percentage deviation of these currencies from the ACU relative to the base period to trace the movement of individual participating regional currencies relative to the ACU. The percent deviation $D_{i, t}$ is defined as

$$
D_{i, t}=\frac{\mathcal{\varepsilon}_{i, t}^{A C U}-\varepsilon_{i, 0}^{A C U}}{\varepsilon_{i, 0}^{A C U}}
$$

with $\varepsilon_{i, 0}^{A C U}$ being the value of the ith currency in terms of the ACU in the base period. Figure 2 traces the percentage deviation of the participating currencies vis-à-vis the ACU. It is evident 
that there is a lot of divergence in the performance of the individual currencies against the ACU with currencies like the Japanese Yen, Chinese Yuan, Singapore Dollar and Thai Bath strengthening vis-à-vis the ACU in 2011 compared to their base year values. On the other hand the Lao Kip, Cambodian Riel, Indonesian Rupiah, Indian Rupee and the Korean Won weakened against the ACU. Moreover, the various currencies did not weaken or strengthen in a monotonic manner, and exhibited significant volatility in the interim period.

Figure 2: Nominal Deviation of the Participating Currencies vis-à-vis the Asian Currency Unit

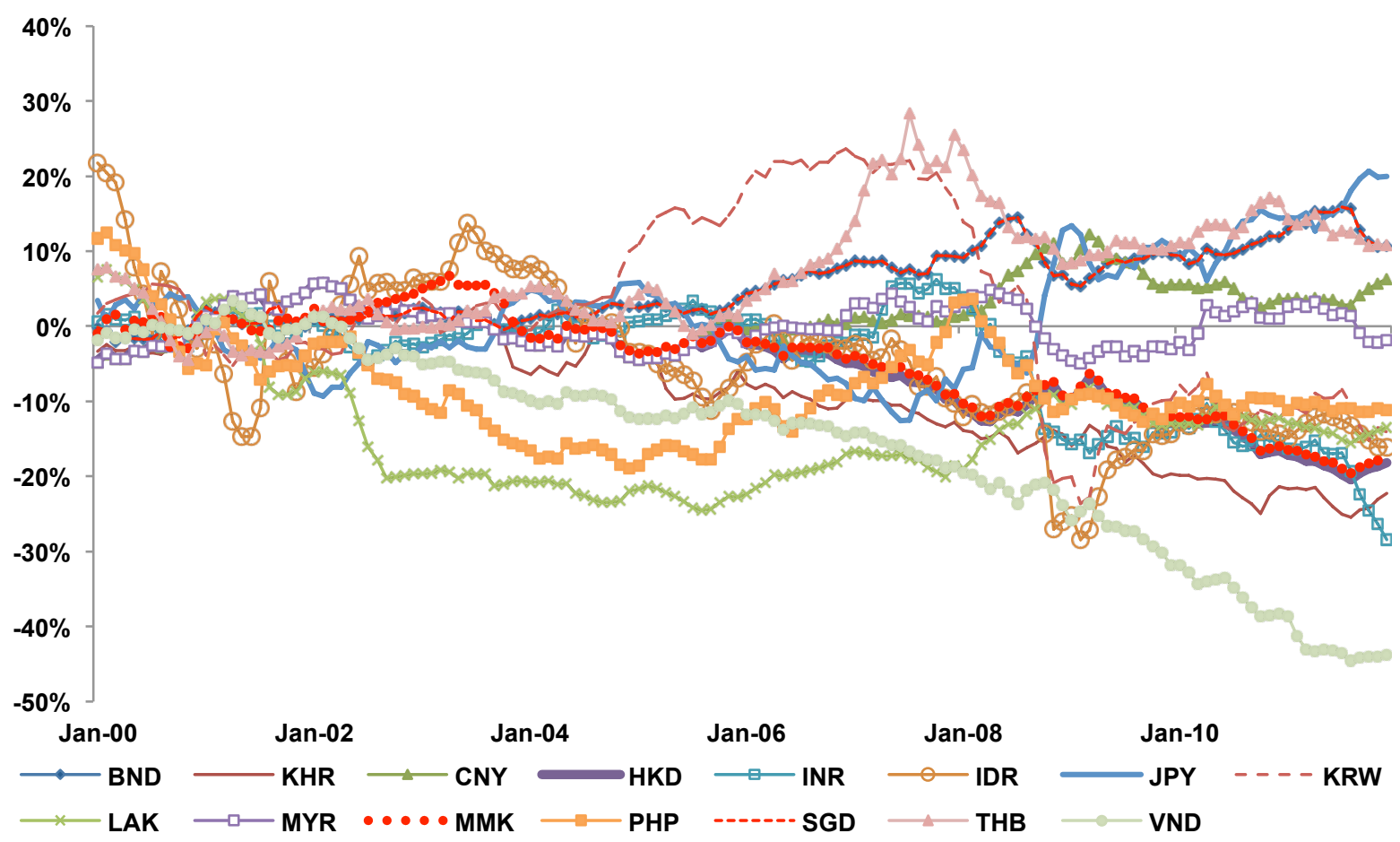

Source: Author's estimates

One possible reason for the large disparity in the nominal exchange rate movements of the participating currencies could be varying inflation rates in these countries. Many countries might aim to have a stable real exchange rate and hence use nominal exchange rate movements to compensate for price changes. To analyze this aspect we focus on the real exchange rate deviations of the participating currencies. The real exchange rate is defined as:

$$
\theta_{i, t}^{A C U}=\varepsilon_{i, t}^{A C U} \frac{P_{t}^{A C U}}{P_{t}^{i}}
$$

where $\theta_{i, t}^{A C U}$ is the real exchange rate, $P_{t}^{A C U}$ is the weighted average price level for the region, and $P_{t}^{i}$ is the price in country $\mathrm{i}$. Thus, following Ogawa and Shimizu (2007), the extent of real exchange rate deviation is calculated by looking at the difference between nominal exchange rate deviation and the inflation differential between the region and the individual country. Inflation is constructed using the consumer price index (CPI). To obtain the inflation for the ACU region, we construct a weighted average of the $\mathrm{CPI}$ for the region with the weights being similar to the ones used for construction of the ACU. Since CPI data are 
available at a monthly frequency the real exchange rate deviation indicators are constructed at a monthly frequency. ${ }^{2}$

In the case of real exchange rate deviation, domestic inflation rates higher than the weighted average for the region add to the appreciation pressure while lower inflation results in depreciation pressure. Figure 3 shows that the extent of real exchange rate deviations, which take into account inflation differentials, are considerably different from the nominal exchange rate deviations. The Japanese Yen, which had appreciated strongly in nominal terms, shows a sustained depreciating trend in real terms due to extremely low and sometimes negative inflation rates prevailing in the Japanese economy during this period. The large weight accorded to Japan in the creation of the regional price index has meant that a number of countries have witnessed inflation rates that are considerably higher than the regional average.

Figure 3: Real Deviation of the Participating Currencies vis-à-vis the Asian Currency Unit

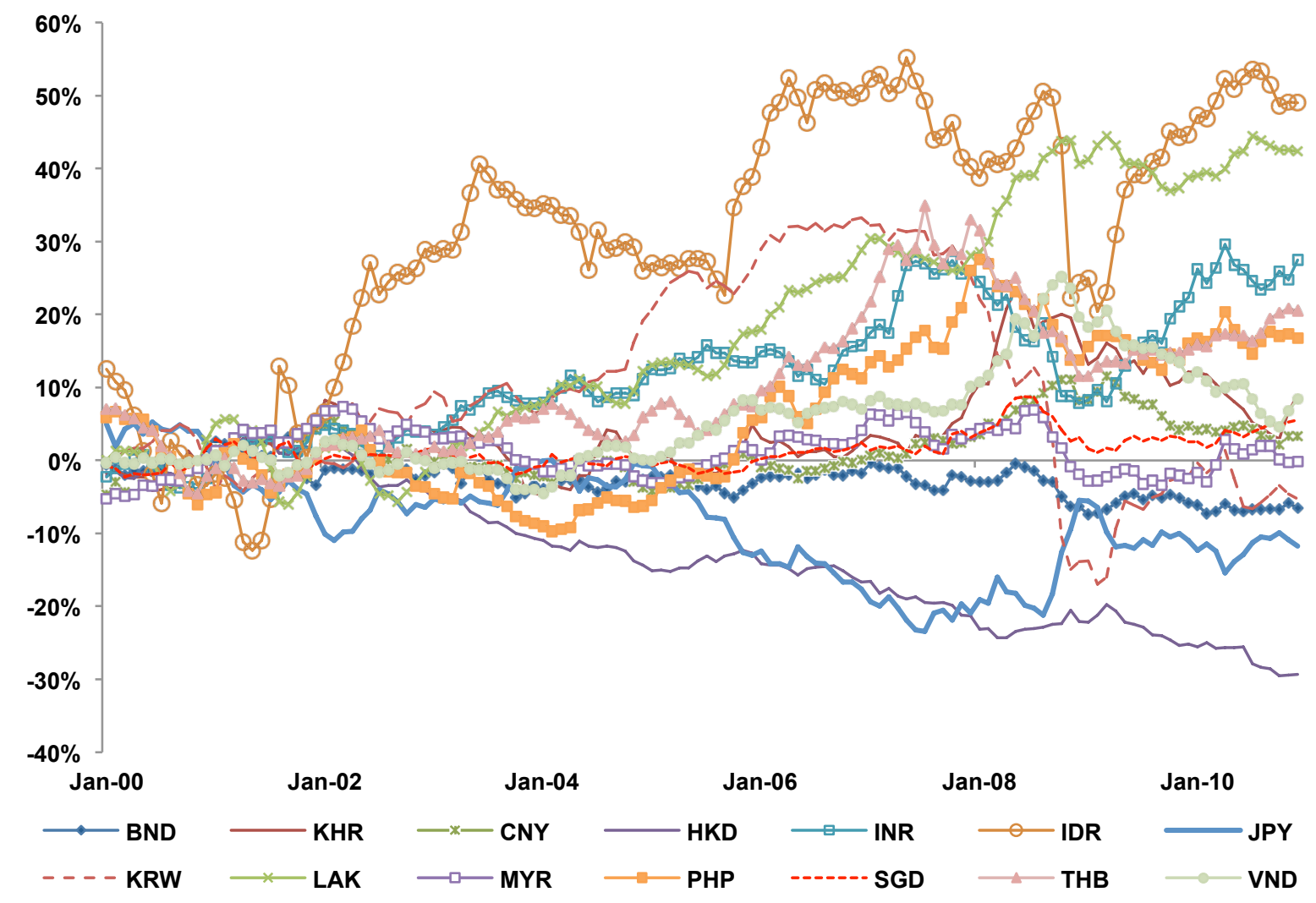

Source: Author's estimates

The Indonesian Rupiah, the Philippine Peso, and the Indian Rupee, which experienced sharp depreciation in nominal terms, exhibited an appreciating trend in real terms due to relatively higher inflation. In the case of the Thai Baht, the appreciation trend gets accentuated when inflation differentials are taken into account. In contrast, due to Hong Kong experiencing inflation levels lower than the regional average, the depreciating trend of the Hong Kong Dollar has increased in real terms.

Next, we focus on whether the extent of the deviation among the participating currencies has increased or declined over time. We look at the movement in the weighted averages of the

\footnotetext{
${ }^{2}$ Data on Consumer Price Index are obtained from the Global Economic Monitor and websites of the central banks and monetary authorities of the participating countries. Owing to a large difference between the inflation rate in Myanmar and weighted inflation rate for the region as a whole, Myanmar is removed from the sample.
} 
nominal and real exchange rate deviation during the period. As described in Equation (5) the weighted average is equal to the weighted sum of absolute deviation of the participating currencies or

$$
W D_{t}=\sum_{i} \omega_{i}\left|D_{i, t}\right|
$$

Figure $4 a$ indicates that the extent of deviation among the nominal exchange rates was relatively stable between 2000 and 2004 . However, since early 2004 there was a sharp increase in the extent of deviation, which peaked prior to the onset global financial crisis. Between late 2008 and end 2009 a number of countries were impacted in a symmetrical manner by global events. The initial flight to safety of foreign capital in the second half of 2008 led to the weakening of many Asian currencies, especially against the US dollar. With signs of recovery since mid-2009, these economies started witnessing an inflow of capital, which allowed many Asian currencies to appreciate. The extent of the deviation among these currencies again started increasing since 2010.

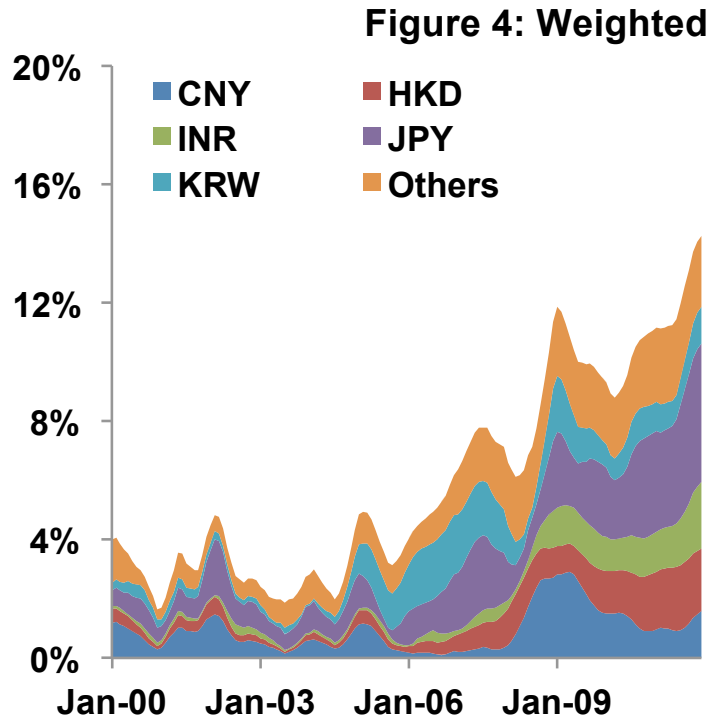

(a) Nominal Deviation

Source: Author's estimates

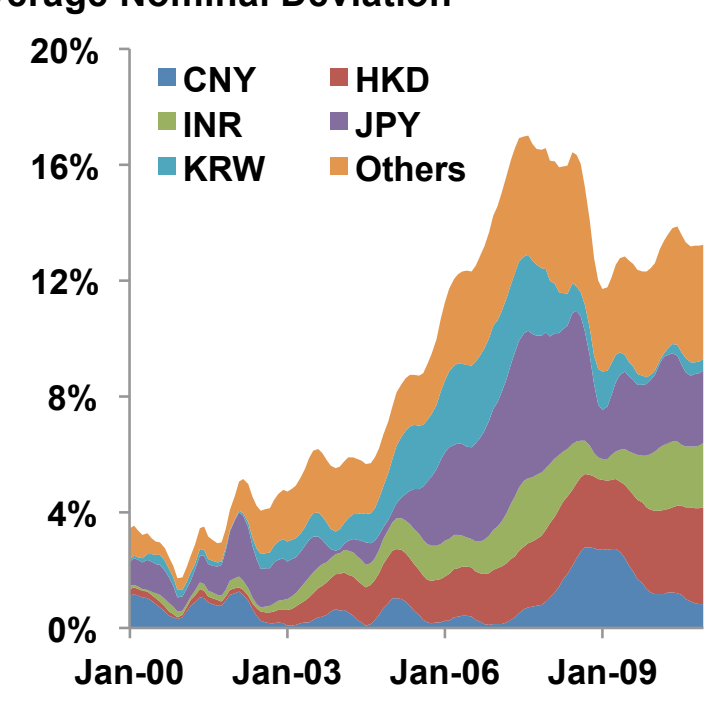

(b) Real Deviation

In the case of real exchange rates also there was a persistent trend of widening deviation between 2001 and the global financial crisis (Figure 4b). The subsequent dip in the extent of real exchange rate deviation was largely due to drop in nominal exchange rate deviation and reduction inflation differential. The strengthening of commodity prices prior to the collapse of Lehman Brothers, and the subsequent dip in commodity prices, had an analogous impact in most of the economies. Much of the movement in the weighted average deviations has been driven by the Japanese Yen and the Korean Won. Recent years have seen increasing contribution from the Hong Kong Dollar and the Indian Rupee as these currencies experienced greater volatility than before.

Finally, the currencies have also exhibited very different degrees of volatility vis-à-vis the Asian Currency Unit, both in the case of nominal deviations as well as real deviations. The recursive standard deviations, outlined in Figure 5, indicate that the most volatile currency was the Indonesian Rupiah, followed by the Japanese Yen and Korean Won. Some currencies, such as the Indian Rupee and Philippine Peso, which exhibited low volatility in terms of nominal deviation, exhibited considerable volatility when real deviations were taken into account, due to differing inflation rates. 


\section{Figure 5: Recursive Estimates of Volatility in Currencies' Deviation vis-à-vis Asian Currency Unit}

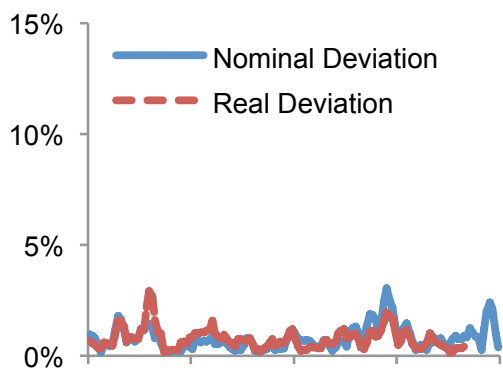

(a) Brunei Dollar

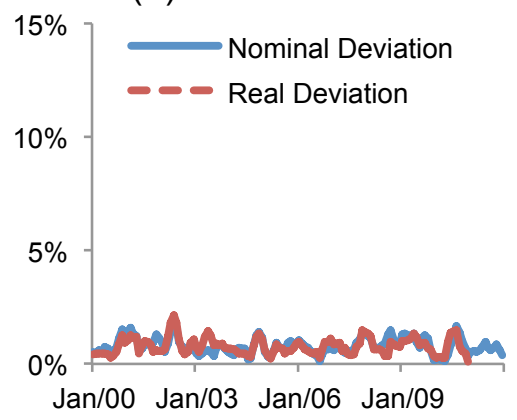

(d) Hong Kong Dollar

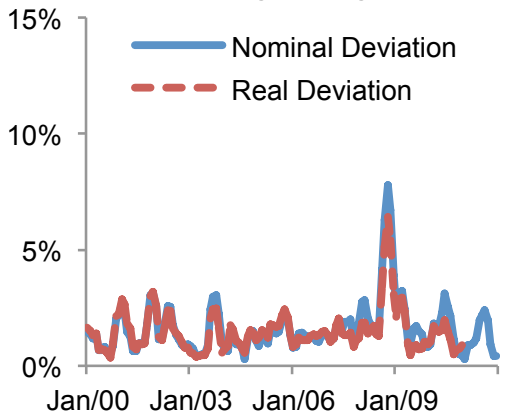

(g) Japanese Yen

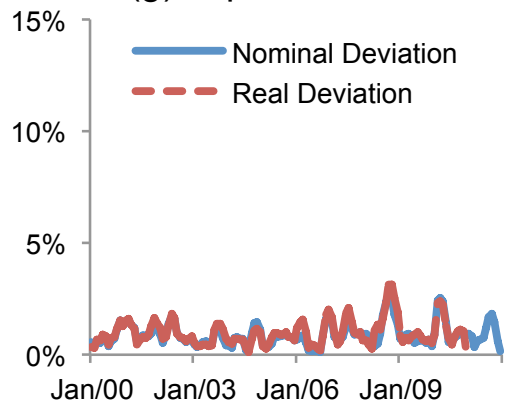

(j) Malaysian Ringgit

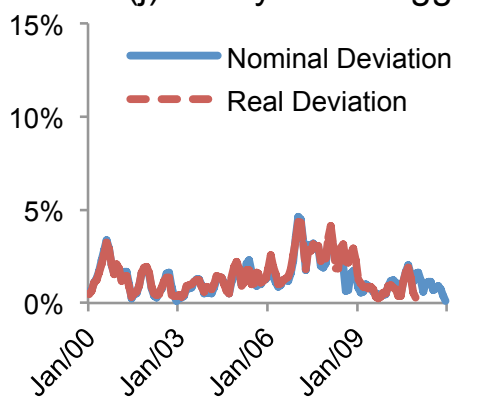

(m) Thai Baht

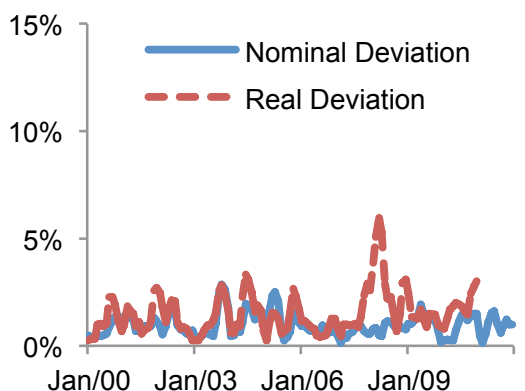

(b) Cambodian Rial

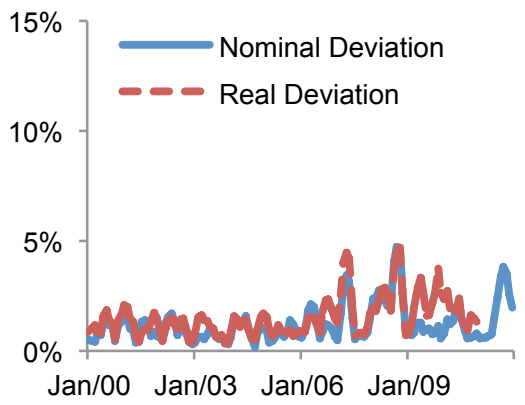

(e) Indian Rupee

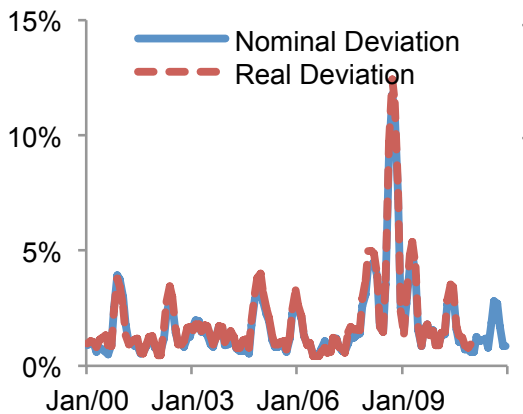

(h) Korean Won

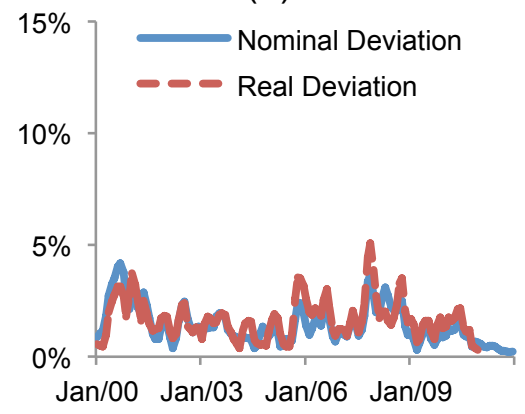

(k) Philippine Peso

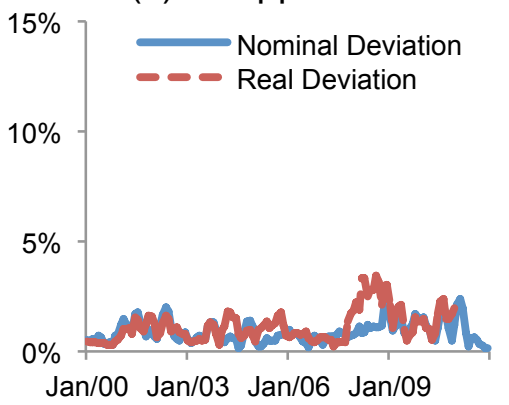

(n) Vietnamese Dong

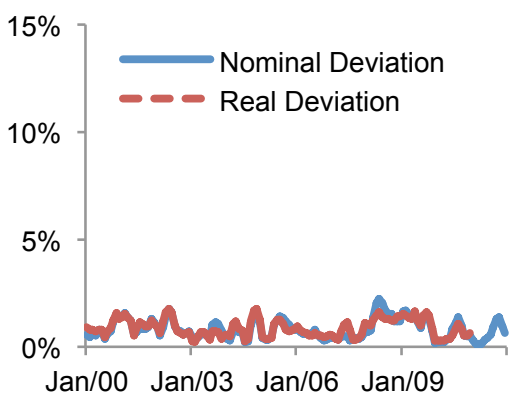

(c) Chinese Yuan

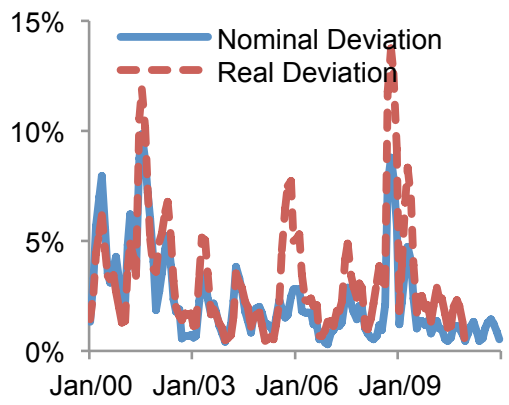

(f) Indonesian Rupiah

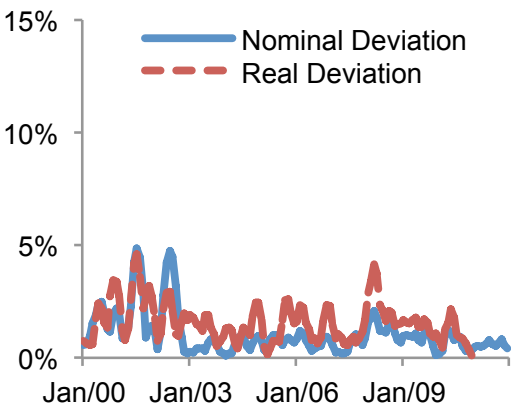

(i) Lao Kip

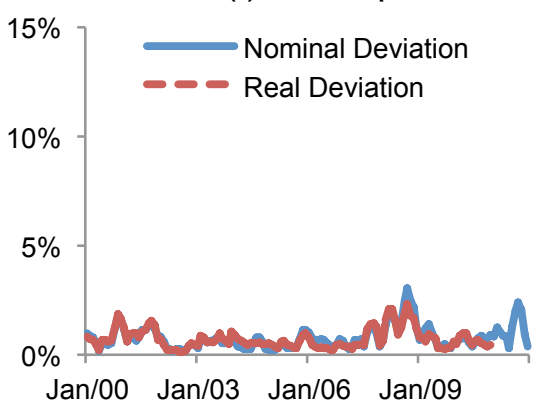

(I) Singapore Dollar

Source: Authors' Estimates 


\subsection{Empirical Estimates}

\subsubsection{Empirical Estimates: No Break Case}

A common approach to examine convergence of a series is to apply the unit root test to examine whether the difference is stationary. The rejection of the unit root hypothesis implies that the time series is stationary and will converge in the long run. However, if these tests fail to reject the hypothesis then the series follows a random path. To evaluate the extent of nominal and real convergence among participating currencies we employ both the Augmented Dickey Fuller (ADF) and the Phillips-Perron test. The results are reported in Columns (1) and (2) in Table 2. As evident, the ADF and the Phillip-Perron tests find little evidence of nominal convergence among participating currencies over the entire period 2000 to 2011, or in any individual year, barring 2001.

Table 2: Convergence among Participating Currencies in Nominal Terms

\begin{tabular}{|c|c|c|c|c|c|c|}
\hline & \multicolumn{2}{|c|}{$\begin{array}{c}\text { Averaged Weighted } \\
\text { Deviation }\end{array}$} & \multicolumn{4}{|c|}{ Panel Unit Root Test } \\
\hline & \multirow[b]{2}{*}{$\begin{array}{l}\text { Augmented } \\
\text { Dickey-Fuller }\end{array}$} & \multirow[b]{2}{*}{$\begin{array}{l}\text { Phillips- } \\
\text { Perron }\end{array}$} & \multicolumn{2}{|c|}{$\begin{array}{l}\text { Assuming Cross Section } \\
\text { Independence }\end{array}$} & \multicolumn{2}{|c|}{ Removing Cross Section Mean } \\
\hline & & & $\begin{array}{l}\text { Im-Pesaran- } \\
\text { Shin }\end{array}$ & $\begin{array}{l}\text { Levin-Lin- } \\
\text { Chu }\end{array}$ & $\begin{array}{l}\text { Im-Pesaran- } \\
\text { Shin }\end{array}$ & $\begin{array}{l}\text { Levin-Lin- } \\
\text { Chu }\end{array}$ \\
\hline & $(1)$ & $(2)$ & $(3)$ & $(4)$ & $(5)$ & $(6)$ \\
\hline $2000-2011$ & -0.328 & -0.342 & 1.761 & 2.956 & 1.780 & 2.105 \\
\hline & $(0.92)$ & $(0.92)$ & $(0.96)$ & $(0.99)$ & $(0.96)$ & $(0.98)$ \\
\hline 2000 & $\begin{array}{l}-1.44 \\
(0.56)\end{array}$ & $\begin{array}{r}-1.916 \\
(0.32)\end{array}$ & $\begin{array}{l}2.862 \\
(0.99)\end{array}$ & $\begin{array}{l}2.151 \\
(0.98)\end{array}$ & $\begin{array}{l}2.953 \\
(0.99)\end{array}$ & $\begin{array}{l}1.122 \\
(0.87)\end{array}$ \\
\hline 2001 & $\begin{array}{l}-1.360^{* *} \\
(0.04)\end{array}$ & $\begin{array}{c}-1.344^{*} \\
(0.06)\end{array}$ & $\begin{array}{c}-0.302^{* *} \\
(0.03)\end{array}$ & $\begin{array}{l}0.824 \\
(0.79)\end{array}$ & $\begin{array}{l}-0.987^{*} \\
(0.06)\end{array}$ & $\begin{array}{c}-0.011^{*} \\
(0.09)\end{array}$ \\
\hline 2002 & $\begin{array}{c}-1.218^{*} \\
(0.07)\end{array}$ & $\begin{array}{c}-1.177^{*} \\
(0.08)\end{array}$ & $\begin{array}{l}1.264 \\
(0.89)\end{array}$ & $\begin{array}{l}-0.614 \\
(0.27)\end{array}$ & $\begin{array}{l}1.639 \\
(0.95)\end{array}$ & $\begin{array}{r}-1.035 \\
(0.15)\end{array}$ \\
\hline 2003 & $\begin{array}{l}-2.37 \\
(0.15)\end{array}$ & $\begin{array}{c}-2.733^{* *} \\
(0.05)\end{array}$ & $\begin{array}{l}2.927 \\
(0.99)\end{array}$ & $\begin{array}{l}1.919 \\
(0.97)\end{array}$ & $\begin{array}{l}1.762 \\
(0.96)\end{array}$ & $\begin{array}{l}1.034 \\
(0.85)\end{array}$ \\
\hline 2004 & $\begin{array}{l}-0.604 \\
(0.87)\end{array}$ & $\begin{array}{l}-0.493 \\
(0.89)\end{array}$ & $\begin{array}{l}1.892 \\
(0.97)\end{array}$ & $\begin{array}{l}2.273 \\
(0.98)\end{array}$ & $\begin{array}{l}2.776 \\
(0.99)\end{array}$ & $\begin{array}{l}2.788 \\
(0.99)\end{array}$ \\
\hline 2005 & $\begin{array}{l}-1.555 \\
(0.51)\end{array}$ & $\begin{array}{l}1.794 \\
(0.38)\end{array}$ & $\begin{array}{l}1.576 \\
(0.94)\end{array}$ & $\begin{array}{l}0.307 \\
(0.62)\end{array}$ & $\begin{array}{l}0.279 \\
(0.61)\end{array}$ & $\begin{array}{r}-0.509 \\
(0.30)\end{array}$ \\
\hline 2006 & $\begin{array}{r}-1.007 \\
(0.75)\end{array}$ & $\begin{array}{l}-0.682 \\
(0.85)\end{array}$ & $\begin{array}{c}-0.990^{* *} \\
(0.05)\end{array}$ & $\begin{array}{c}-1.176^{* *} \\
(0.03)\end{array}$ & $\begin{array}{c}-1.612^{* *} \\
(0.04)\end{array}$ & $\begin{array}{c}-2.336^{* * *} \\
(0.01)\end{array}$ \\
\hline 2007 & $\begin{array}{l}-2.148 \\
(0.22)\end{array}$ & $\begin{array}{r}-2.226 \\
(0.19)\end{array}$ & $\begin{array}{c}2.0405 \\
(0.98)\end{array}$ & $\begin{array}{l}1.445 \\
(0.93)\end{array}$ & $\begin{array}{l}2.227 \\
(0.98)\end{array}$ & $\begin{array}{l}1.629 \\
(0.95)\end{array}$ \\
\hline 2008 & $\begin{array}{l}-0.486 \\
(0.89)\end{array}$ & $\begin{array}{r}-0.514 \\
(0.89)\end{array}$ & $\begin{array}{l}2.062 \\
(0.98)\end{array}$ & $\begin{array}{l}0.191 \\
(0.58)\end{array}$ & $\begin{array}{l}1.553 \\
(0.94)\end{array}$ & $\begin{array}{l}-0.664 \\
(0.25)\end{array}$ \\
\hline 2009 & -1.651 & -1.577 & 0.696 & 1.135 & 1.440 & 1.848 \\
\hline & $(0.45)$ & $(0.49)$ & $(0.76)$ & $(0.87)$ & $(0.92)$ & $(0.97)$ \\
\hline 2010 & $\begin{array}{r}-1.235 \\
(0.66)\end{array}$ & $\begin{array}{r}-1.177 \\
(0.68)\end{array}$ & $\begin{array}{l}0.258 \\
(0.60)\end{array}$ & $\begin{array}{r}-0.109 \\
(0.46)\end{array}$ & $\begin{array}{l}1.204 \\
(0.88)\end{array}$ & $\begin{array}{l}0.482 \\
(0.68)\end{array}$ \\
\hline 2011 & -0.059 & -0.033 & 0.869 & 1.067 & 1.552 & 3.066 \\
\hline & $(0.95$ & $(0.96)$ & $(0.80)$ & $(0.86)$ & $(0.94)$ & $(0.99)$ \\
\hline
\end{tabular}

Note: P-values in brackets. ${ }^{* *},{ }^{* *}$, and ${ }^{*}$ imply significance at $1 \%, 5 \%$ and $10 \%$ respectively. Source: Author's calculations.

However, as shown by Fan and Wei (2006) a constraint of these tests is that they have low power as they tend to reject overly the stationarity hypothesis of a time series. To account for this shortcoming we also focus on panel unit root tests.

The benchmark test of exchange rate convergence is based on the stochastic model given by Equation (6) below:

$$
D_{i, t}=\alpha_{i}+\rho D_{i, t}+\mu_{i, t}
$$

where $\mathrm{i}$ is country index, $\alpha_{i}$ is the idiosyncratic factor in country $\mathrm{i}$ and $\mu_{i, t}$ is a white noise error term. This can be reformulated as Equation (7). 


$$
\Delta D_{i, t}=\alpha_{i}+\psi_{i} D_{i, t-1}+\sum_{j=}^{\rho_{i}} \xi_{j} \Delta D_{i, t-j}+\mu_{i, t}
$$

Here $\psi>0$ implies an explosive process, $\psi=0$ describes random walk behaviour, $\psi<0$ and implies stationary process and convergence.

To test the stationarity, we employ the Levin-Lin-Chu test developed by Levin et al. (2002) and the Im-Pesaran-Shin test developed by Im et al. (2003). The methodologies in both these tests have been developed from a multivariate generalization of the ADF test. A limitation of the Levin-Lin-Chu test is that it imposes a cross-equation restriction on the first order autocorrelation coefficients. In contrast, Im-Pesaran-Shin test allows these coefficients to differ across panel members. Moreover, the Levin-Lin-Chu test requires the panels to be strongly balanced, while the Im-Pesaran-Shin test works with unbalanced panel. To ensure a balanced panel we restrict our dataset on nominal deviation between January 2000 and September 2011. Again, as can be seen from Columns (3) and (4) of Table 2, these tests are also unable to reject the null hypothesis that average weighted deviation has unit root over the entire sample from 2000 to 2011 . When we split the sample on a yearly basis it is observed that in 2001 and 2002 there was some evidence of exchange rate convergence, but in the subsequent years there is no such evidence.

The above tests assume that the individual panels have cross section independence. However, the assumption of cross section independence is rarely found in practice, especially in a globalized worlds where shocks transmit easily from one country to another. This was clearly evident in the case of the Global Financial Crisis in 2008 and 2009. These facts question the validity of the assumption of cross-section independence.

In order to account for cross sectional independence, we relax the independence assumption to allow for time-varying aggregate effects in the data. These effects can be removed by subtracting the cross section mean from the data. The optimal lag length is selected by using the Akaike Information Criteria. The results obtained by removing the cross section mean are reported in Columns (5) and (6) of Table 2. The results again indicate that both for the whole sample as well as for most years it is not possible to reject the null hypothesis of unit root.

Table 3: Convergence among Participating Currencies in Real Terms

\begin{tabular}{|c|c|c|c|c|c|c|}
\hline & \multicolumn{2}{|c|}{ Averaged Weighted Deviation } & \multicolumn{4}{|c|}{$\begin{array}{c}\text { Panel Unit Root Test } \\
\end{array}$} \\
\hline & & & \multicolumn{2}{|c|}{$\begin{array}{l}\text { Assuming Cross Section } \\
\text { Independence }\end{array}$} & \multicolumn{2}{|c|}{ Removing Cross Section Mear } \\
\hline & $\begin{array}{l}\text { Augmented } \\
\text { Dickey-Fuller }\end{array}$ & $\begin{array}{l}\text { Phillips- } \\
\text { Perron }\end{array}$ & $\begin{array}{l}\text { Im-Pesaran- } \\
\text { Shin }\end{array}$ & $\begin{array}{l}\text { Levin-Lin- } \\
\text { Chu }\end{array}$ & $\begin{array}{l}\text { Im-Pesaran- } \\
\text { Shin }\end{array}$ & $\begin{array}{l}\text { Levin-Lin- } \\
\text { Chu }\end{array}$ \\
\hline & (1) & $(2)$ & (3) & (4) & (5) & (6) \\
\hline \multirow[t]{2}{*}{ 2000-2010 } & -1.177 & -0.888 & 0.221 & -0.536 & 0.316 & -1.099 \\
\hline & (0.68) & (0.79) & (0.59) & $(0,29)$ & $(0.62)$ & (0.13) \\
\hline \multirow[t]{2}{*}{ 2000-2001 } & -1.81 & -1.916 & $-1.257^{*}$ & $-1.912 * *$ & -0.533 & $-1.393^{*}$ \\
\hline & $(0.37)$ & $(0.32)$ & -0.09 & $(0.02)$ & $(0.30)$ & $(0.09)$ \\
\hline \multirow[t]{2}{*}{ 2002-2003 } & -1.857 & -1.273 & 0.531 & -2.927 & $-2.078 * *$ & $-5.087 * * *$ \\
\hline & $(0.35)$ & $(0.64)$ & (0.71) & (0.19) & $(0.02)$ & $(0.00)$ \\
\hline \multirow[t]{2}{*}{ 2004-2005 } & -0.227 & -0.191 & 1.578 & 1.896 & 2.523 & 1.676 \\
\hline & (0.93) & $(0.94)$ & (0.94) & (0.97) & (0.99) & (0.95) \\
\hline \multirow[t]{2}{*}{ 2006-2007 } & 0.138 & 0.084 & 2.471 & -0.124 & 3.111 & -0.999 \\
\hline & $(0.97)$ & $(0.97)$ & (0.99) & $(0.45)$ & (0.99) & $(0.16)$ \\
\hline \multirow[t]{2}{*}{ 2008-2010 } & $-2.453^{*}$ & $-2.787^{*}$ & $-2.172 * *$ & $-1.584 * *$ & $-2.964 * *$ & $-2.693 * *$ \\
\hline & (0.10) & $(0.06)$ & $(0.02)$ & $(0.05)$ & $(0.02)$ & (0.02) \\
\hline
\end{tabular}

Note: P-values in brackets. ${ }^{* *},{ }^{* *}$, and ${ }^{*}$ imply significance at $1 \%, 5 \%$ and $10 \%$ respectively. Source: Author's calculations. 
Next, we turn our attention to convergence in real terms. Again, with a view to work with balanced dataset, and based on the availability of inflation data, we restrict our sample from January 2000 to December 2010. Table 3 outlines the key results. Since real exchange rate deviation is available only on a monthly basis, to ensure adequate degrees of freedom, the data is split by including data for two years at a time. A similar result is obtained where for the entire period as well as the sub samples, there is little evidence of convergence. Even correcting for cross sectional dependence does not change the overall conclusion. Some evidence of convergence is observed during 2008-2010. As discussed above, this might be due to the simultaneous weakening of most currencies during the global financial crisis, and their subsequent revival once capital flows resumed. Moreover, the rise in commodity prices prior to the crisis and their subsequent slump also affected these economies in a coordinated manner.

\subsubsection{Empirical Estimates: Allowing Endogenously Determined Structural Breaks}

A wide array of studies including Amsler and Lee (1995) has argued the biasness of unit root tests toward accepting the false unit root null hypothesis, especially in the presence of a structural break. The failure of taking into account structural breaks often results in a significant loss of power in unit root tests. Similarly, stationarity tests, which ignore the existence of breaks, tend to diverge and tend to be biased toward rejecting the null hypothesis of stationarity in favour of the false alternative of a unit root hypothesis. This is driven by severe size distortion caused by the presence of breaks.

In order to account for this feature, we compute the extension of the Hadri (2000) test for stationarity in panel data with multiple structural changes under the null hypothesis, which is proposed in Carrion-i-Silvestre et al. (2005). The framework allows for a number of variations including multiple structural changes, multiple structural changes positioned in different unknown dates and different number of breaks for each individual. To date the breaks, Carrion-i-Silvestre et al. (2005) apply the procedure proposed in Bai and Perron (1998), which involves specifying a maximum number of breaks $\left(m^{\max }\right)$, estimating their position for each $m_{i} \leq m^{\max }, i=\{1, \ldots . . N\}$, testing for the significance of the breaks, and then obtaining their optimum number and position for the various individual series.

These breaks and the corresponding phases across the 15 Asian currencies' nominal deviation from the Asian Currency Unit are highlighted in Figure 6. Again, there is clear evidence of variation in both the number and timing of structural breaks experienced by the various countries as well as duration of a phase. In general, at least one structural break was detected using the sequential procedure used in all the countries considered. While the Indian Rupee experienced only one break, Cambodian Real, Chinese Yuan, Hong Kong Dollar, Malaysian Ringgit, Myanmar Kyat and Vietnamese Dong witnessed five breaks.

Figure 7 focuses on the structural break in the case of 15 Asian currencies' real deviation from the Asian Currency Unit. ${ }^{3}$ Like in the case of nominal deviations, here also there is a great deal of disparity in the number and timing of these structural breaks, thereby providing very little evidence of exchange rate coordination in real terms. Moreover, there is significant variation in the nature of structural breaks among currencies' real and nominal deviation, indicating that inflation has impacted the different currency in various forms.

The test further involves the following regressions which encompass $i=1, \ldots . . N$ individuals and $t=1, \ldots . T$ time periods.

\footnotetext{
${ }^{3}$ Owing to a large difference between the inflation rate in Myanmar and weighted inflation rate for the region as a whole, Myanmar is removed from the sample while identifying structural breaks.
} 


$$
y_{i, t}=\alpha_{i, t}+\beta_{i} t+\varepsilon_{i, t}
$$

and

$$
\alpha_{i, t}=\sum_{k=1}^{m_{i}} \theta_{i, k} D\left(T_{b, k}^{i}\right)_{i}+\sum_{k=1}^{m_{i}} \gamma_{i, k} D U_{i, k, t}+\alpha_{i, t-1}+v_{i, t}
$$

where $v_{i, t} \sim\left(0, \sigma_{v, i}^{2}\right)$ and $\alpha_{i, 0}=\alpha_{i}$, a constant. The dummy variables $D\left(T_{b, k}^{i}\right)$ and $D U_{i, k, t}$ are defined as $D\left(T_{b, k}^{i}\right)=1$ for $t=T_{b, k}^{i}+1$ and 0 elsewhere, and $D U_{i, k, t}=1$ for $t>T_{b, k}^{i}$ and 0 elsewhere, with $T_{b, k}^{i}$ giving the $\mathrm{k}^{\text {th }}$ date of the break for the $\mathrm{i}^{\text {th }}$ individual, $k=1, \ldots . . m_{i}, m_{i} \geq 1$. Furthermore, the stochastic processes $\left\{\varepsilon_{i, t}\right\}$ and $\left\{v_{i, t}\right\}$ are mutually independent across the two dimensions of the panel data set. With $\sigma_{v, i}^{2}=0$ for all $i=1, \ldots . . N$, i.e. the null hypothesis of a stationarity panel and substituting (10) in (9) leads to

$$
y_{i, t}=\alpha_{i}+\sum_{k=1}^{m_{i}} \theta_{i, k} D U_{i, k, t}+\beta_{i} t \sum_{k=1}^{m_{i}} \gamma_{i, t} D T_{i, k, t}^{*}+\varepsilon_{i, t}
$$

with the dummy variable $D T_{i, k, t}^{*}=t-T_{b, k}^{i}$ for $t>T_{b, k}^{i}$ and 0 elsewhere $k=1, \ldots . . m_{i}, m_{i} \geq 1$.

The test of the null hypothesis relies on a test statistic which is the average of the univariate stationarity tests in KPSS. The test statistic is given by

$$
\begin{aligned}
& L M(\lambda)=N^{-1} \sum_{t=1}^{N}\left(\widehat{\omega}^{-2} T^{-2} \sum_{t=1}^{T} \hat{S}_{i, t}^{2}\right) \text { for the homogenous case } \\
& L M(\lambda)=N^{-1} \sum_{t=1}^{N}\left(\widehat{\omega}_{i}^{-2} T^{-2} \sum_{t=1}^{T} \hat{S}_{i, t}^{2}\right) \text { for the heterogeneous case }
\end{aligned}
$$

where $\hat{S}_{i, t}^{2}=\sum_{j=1}^{t} \hat{\epsilon}_{i, j}$ denotes the partial sum process that is obtained using the estimated OLS residuals of $\mathrm{XX}$, with $\widehat{\omega}_{i}^{2}$ being a consistent estimate of the long-run variance of $\varepsilon_{i, t}$, $\omega_{i}^{2}=\lim _{T \rightarrow \infty} T^{-1} E\left(\left(S_{i, T}^{2}\right)\right.$ and $\widehat{\omega}^{2}=N^{-1} \sum_{t=1}^{N}\left(\widehat{\omega}_{i}^{-2}\right)$. The $\lambda$ used in equations (12) and (13) refer to the dependence of the test on the dates of the break. For each individual $i$, it is defined as the vector $\lambda_{i}=\left(\lambda_{i, 1}, \ldots \ldots \ldots, \lambda_{i, m_{i}}\right)^{\prime}=\left(T_{b, 1}^{i} / T, \ldots \ldots . ., T_{b, m_{i}}^{i} / T\right)$ which indicates the relative positions of the breaks on the entire time period T. Finally, we define $\bar{\xi}=\sum_{i=1}^{N} \xi_{i}$ and $\bar{\zeta}^{2}=\sum_{i=1}^{N} \zeta_{i}^{2}$, with $\xi_{i}$ and $\zeta_{i}^{2}$ the individual mean and variance of $\eta_{i}\left(\lambda_{i}\right)$, respectively, the test statistic for the null hypothesis of a stationary panel with multiple shifts is given by

$$
Z(\lambda)=\frac{\sqrt{N}(L M(\lambda)-\bar{\xi})}{\bar{\zeta}} \stackrel{d}{\longrightarrow} N(0,1)
$$


Figure 6: Structural Breaks in Currencies' Nominal Deviation vis-à-vis Asian Currency Unit

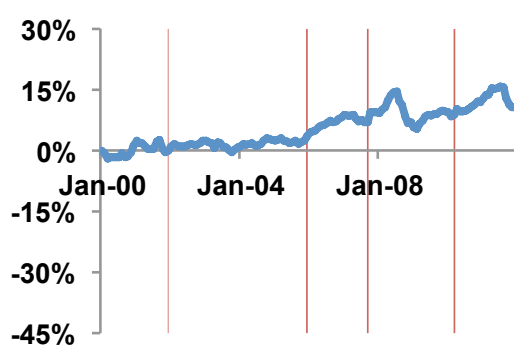

(a) Brunei Dollar

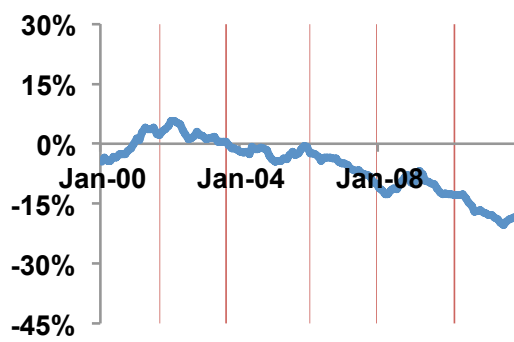

(d) Hong Kong Dollar

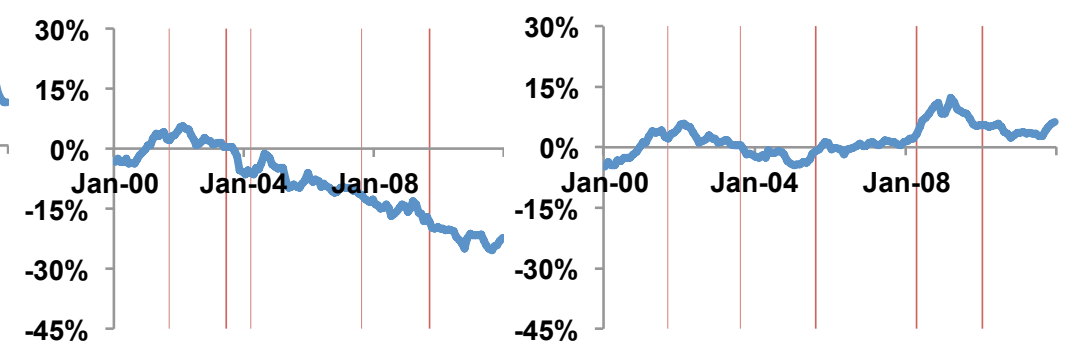

(b) Cambodian Rial

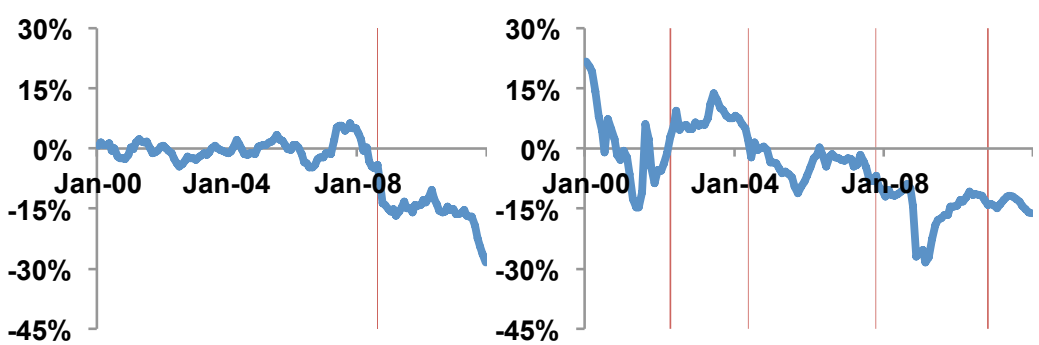

(e) Indian Rupee

(f) Indonesian Rupiah

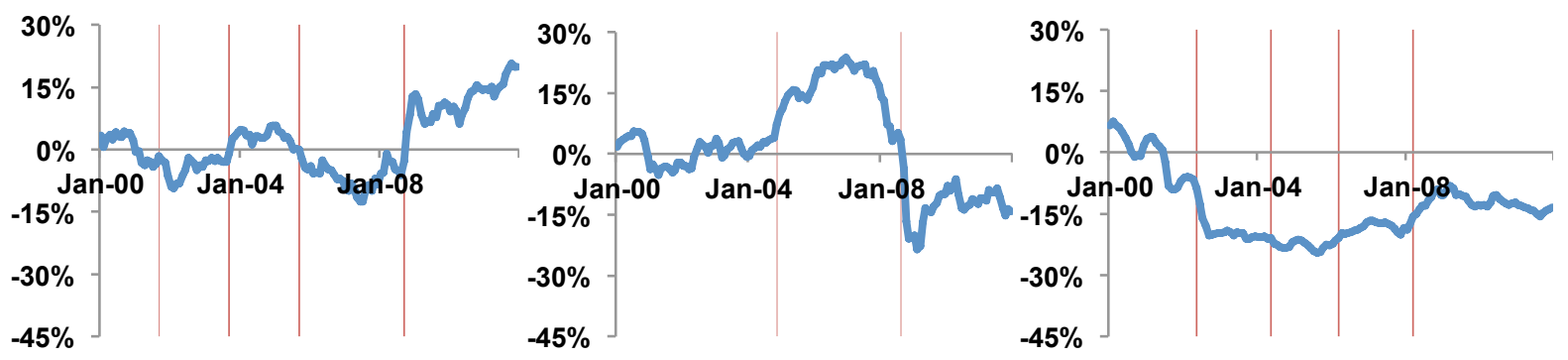

(g) Japanese Yen

(h) Korean Won

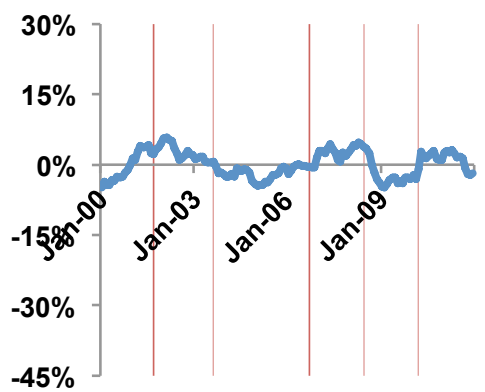

(j) Malaysian Ringgit

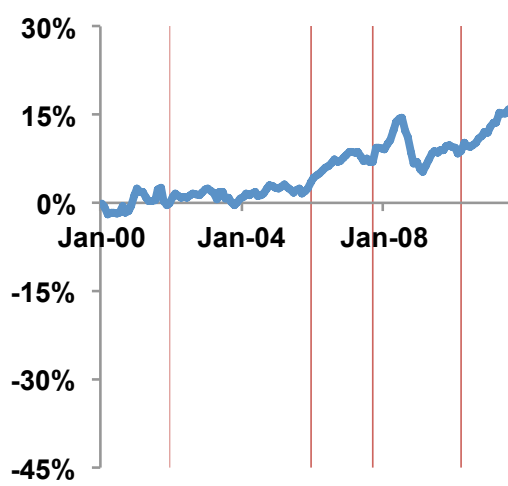

(m) Singapore Dollar

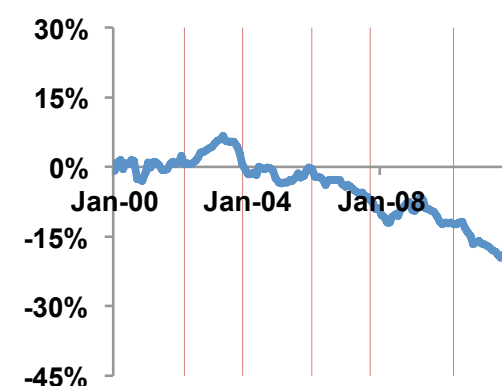

(k) Myanmar Kyat

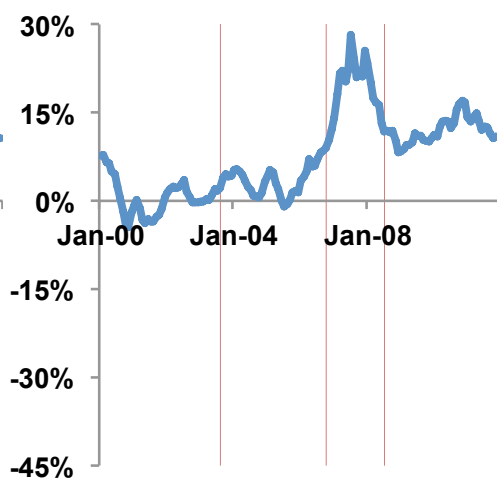

(n) Thai Baht (i) Lao Kip

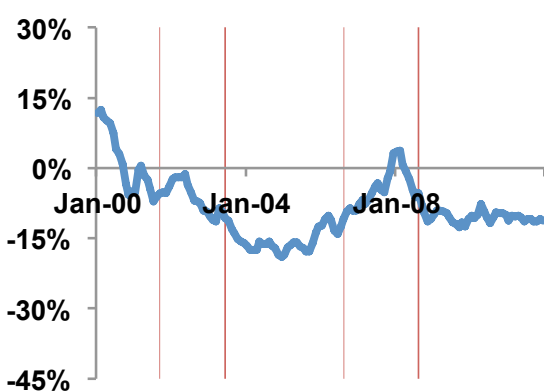

(I) Philippine Peso

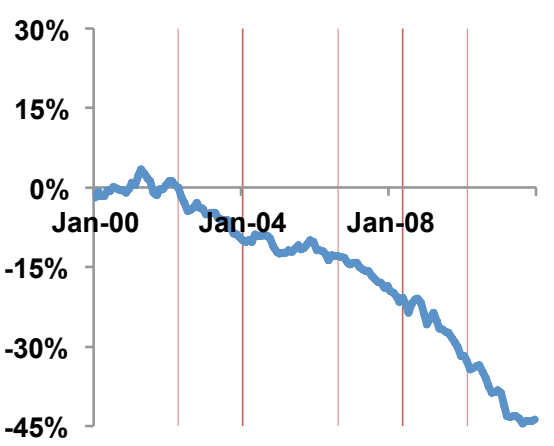

(o) Vietnamese Dong Source: Authors' Estimates 
Figure 7: Structural Breaks in Currencies' Real Deviation vis-à-vis Asian Currency Unit

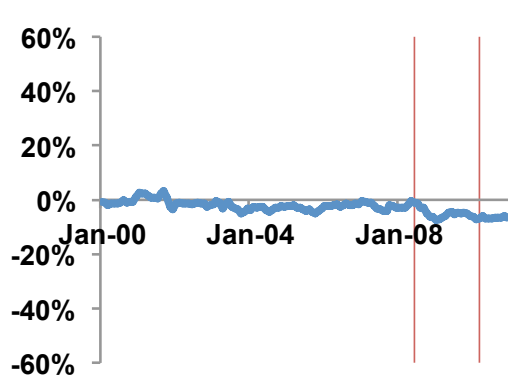

(a) Brunei Dollar

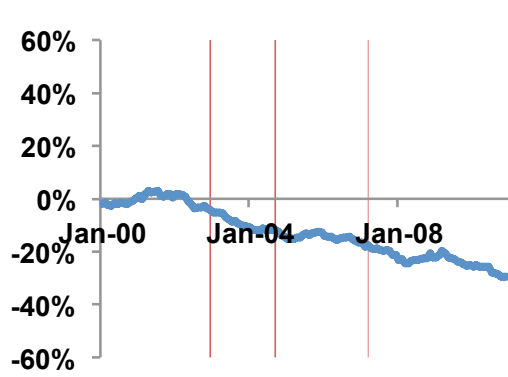

(d) Hong Kong Dollar

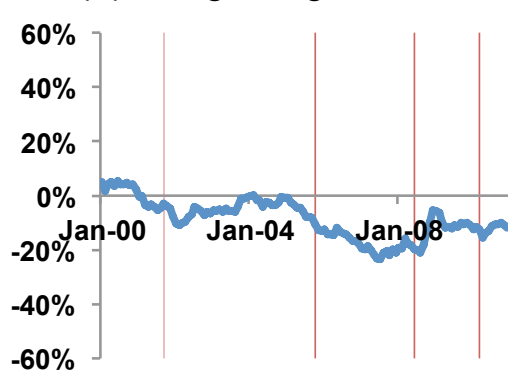

(g) Japanese Yen
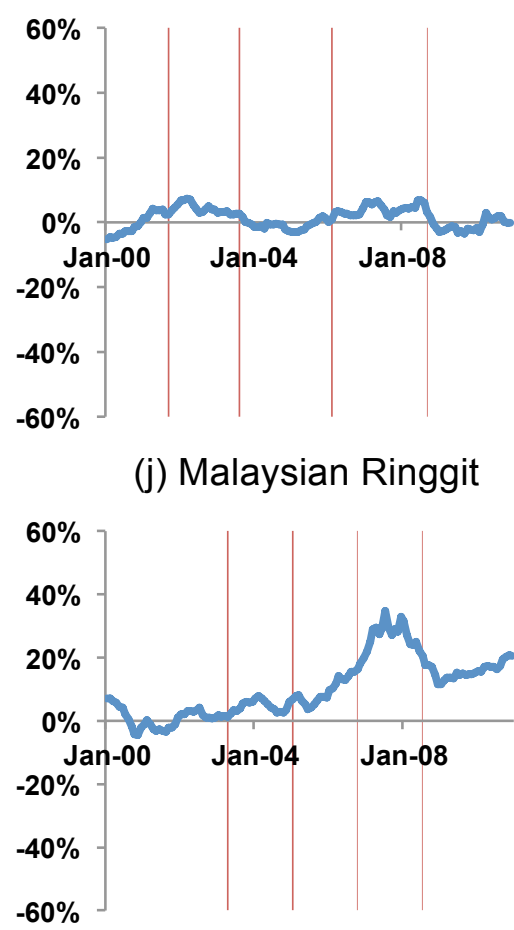

(m) Thai Baht

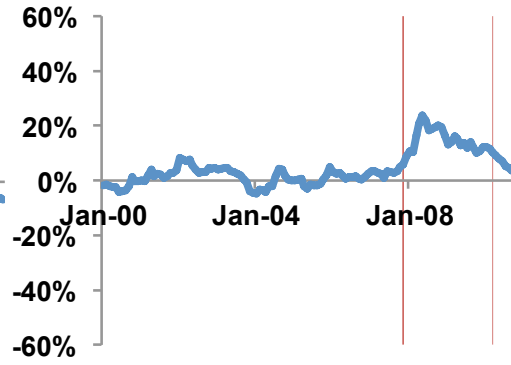

(b) Cambodian Rial

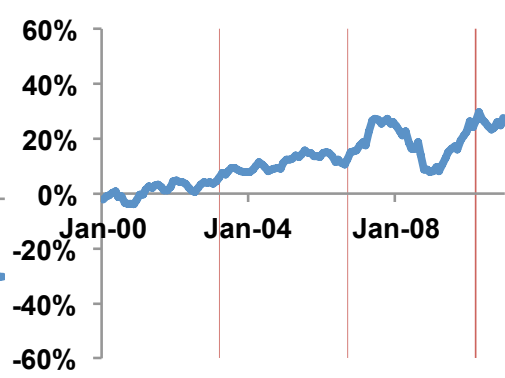

(e) Indian Rupee

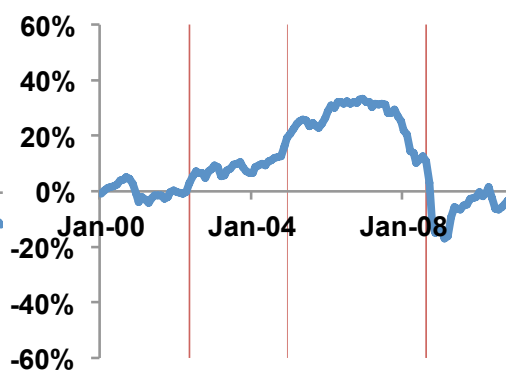

(h) Korean Won

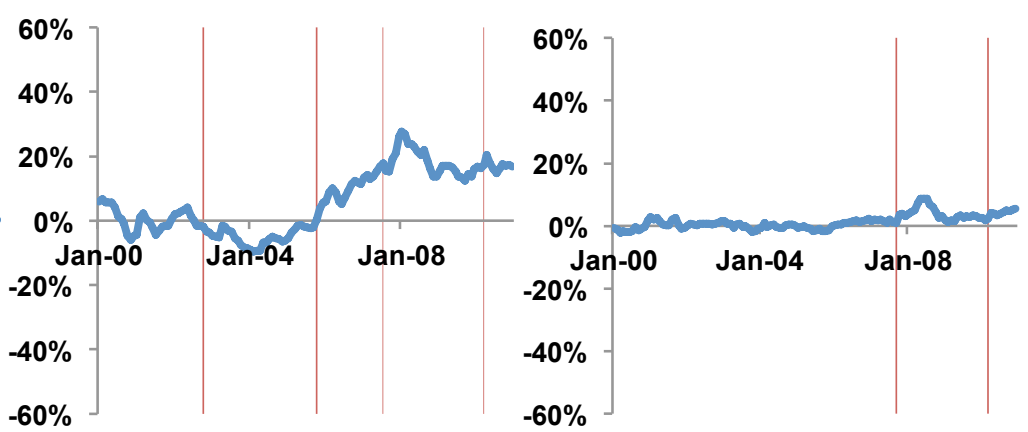

(k) Philippine Peso

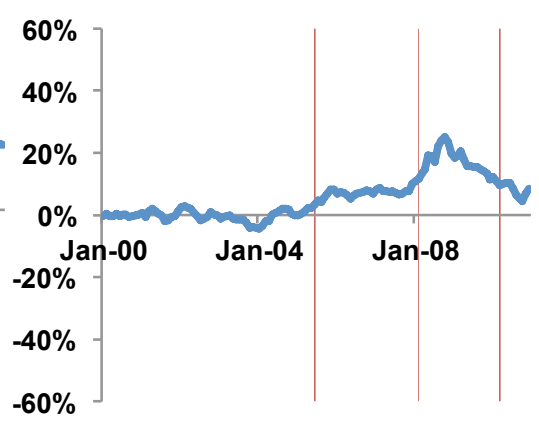

(n) Vietnamese Dong

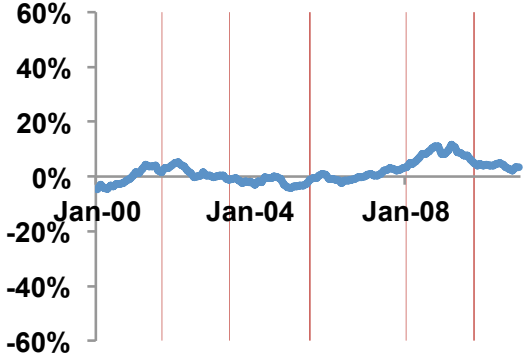

(c) Chinese Yuan

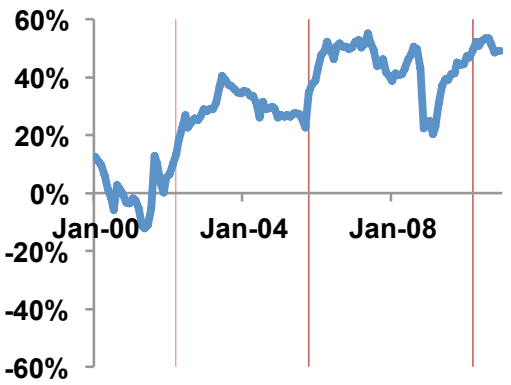

(f) Indonesian Rupiah

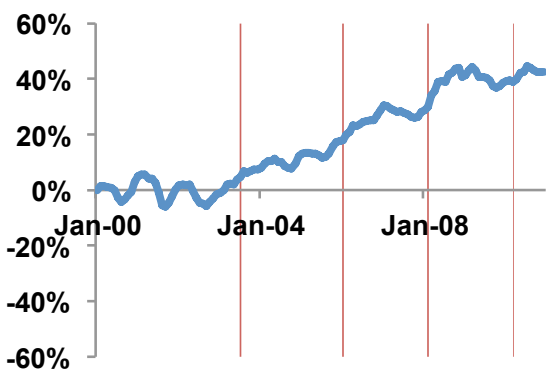

(i) Lao Kip
(I) Singapore Dollar

Source: Authors' Estimates 
The test statistic allows each time series to have a different numbers of breaks located at different dates. We use the breaks identified in Figure 6 and Figure 7 using the procedure outlined in Bai and Perron (1998).

Table 4: Panel Data Stationarity Tests with Multiple Structural Breaks

\begin{tabular}{|l|c|c|}
\hline & Nominal Deviation & Real Deviation \\
\hline Homogenous & $-3.822^{* *}$ & $-0.177^{\star *}$ \\
& $(0.025)$ & $(0.031)$ \\
\hline Heterogenous & $-3.193^{* *}$ & -1.812 \\
& $(0.047)$ & $(0.152)$ \\
\hline
\end{tabular}

Note: P-values in brackets. ${ }^{* * *},{ }^{* *}$, and ${ }^{*}$ imply significance at $1 \%, 5 \%$ and $10 \%$ respectively. Source: Author's calculations.

Table 4 provides the results of the panel stationarity test. The null hypothesis of stationarity can be rejected when the test is computed using the homogenous long run variance estimate for both nominal and real deviation. Only in the case of real deviations from the Asian Currency Unit under the assumption of heterogenous long run variance, the null hypothesis of panel stationarity cannot be rejected. With overall evidence in favour of a rejection being quite overwhelming, one can conclude that the Asian currencies have shown very little indication of convergence in nominal terms. The evidence of real deviation is slightly more mixed with the homogenous and heterogenous long run variance presenting conflicting evidence. This could be driven by similar movement in the currencies and inflation rates in the post 2007 period.

\section{Diverse Exchange Rate Regimes}

The diverse movement in participating countries' currencies is explained primarily by the different exchange rate regimes followed by these countries. This divergence in exchange rate regimes signals the difference in the priorities of the monetary and exchange rate policy. In a number of Asian economies the exchange rate serves as the nominal anchor or intermediate target of monetary policy. In these countries, the monetary authority intervenes in the foreign exchange market to maintain the exchange rate at its predetermined level or within a range. In these countries, the domestic currency can be tied to a major global currency like the US dollar, a basket of currencies, or some regional currency. ${ }^{4}$

Many of the developed and some of the emerging economies of the region have resorted to inflation targeting. This requires a greater degree of exchange rate flexibility as monetary policy decisions are guided by the deviation of forecasts of future inflation from the announced inflation target. Finally, some countries do not resort to a single explicit nominal anchor but monitor various indicators in conducting monetary policy. Table 4 lists the exchange rate regimes practiced by the participating countries according to the IMF's de facto classification of exchange rates regimes and monetary framework.

According to the IMF classification, most of the Asian economies are either completely fixed (hard or soft) or managed floaters. The only exceptions are Japan, Korea and Philippines. In the case of the latter two, the assertion is at odds with the fact that both the countries had been accumulating reserves till the onset of the global financial crisis.

Over the last decade a small amount of literature on data-driven methods for the classification of exchange rate regimes has developed (Reinhart and Rogoff (2004) and Levy-Yeyati and Sturzenegger (2005)). This literature has classified exchange rate regimes in operation using a variety of alternative algorithms. Such a classification helps in analyzing the evolution of a country's exchange rate regime over a period.

\footnotetext{
${ }^{4}$ The Brunei dollar is tied to the Singapore dollar in a 1:1 ratio.
} 
Table 4: Classification of Exchange Rates Regimes and Monetary Framework

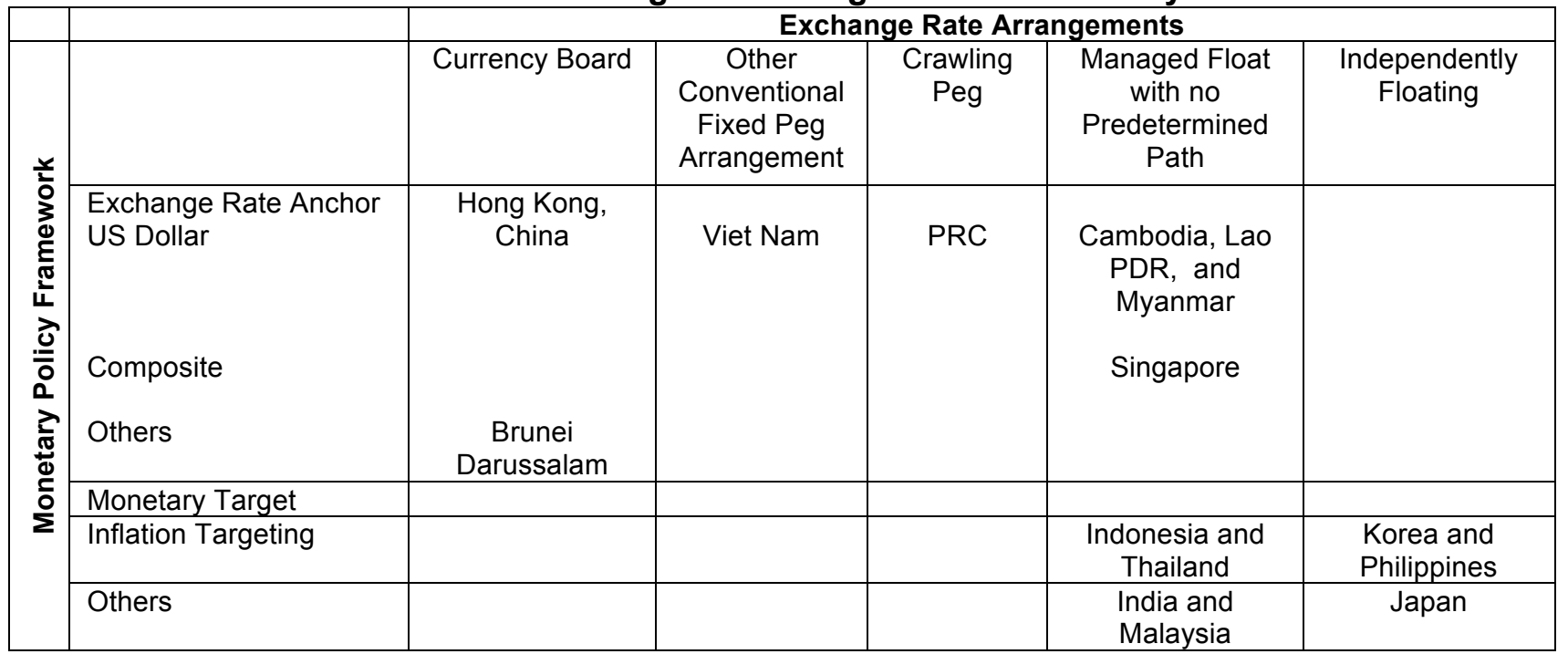

Source: IMF(2009)

Figure 8 highlights the evolution of exchange regimes in the participating countries during 2000 to 2010 according to Reinhart and Rogoff (2004) classification. It is evident that exchange rate regimes in the participating countries continue to be quite diverse, ranging from currency board arrangement in Hong Kong and managed floating in Korea to freely floating in Japan. Furthermore, 10 out of the 15 countries in our sample0 witnessed virtually no change in their exchange rate regimes between 2000 and 2010. Moreover countries such as PRC did experience a shift in the exchange rate regime in the mid-2000s towards more flexibility. It was only a handful of countries such as However, this was a short-lived transition, and PRC reverted back to its original regime in late 2000s. It was only a handful of countries such as India, Malaysia and Philippines, which moved towards greater flexibility.

Figure 8: De Facto Exchange Rate Regimes

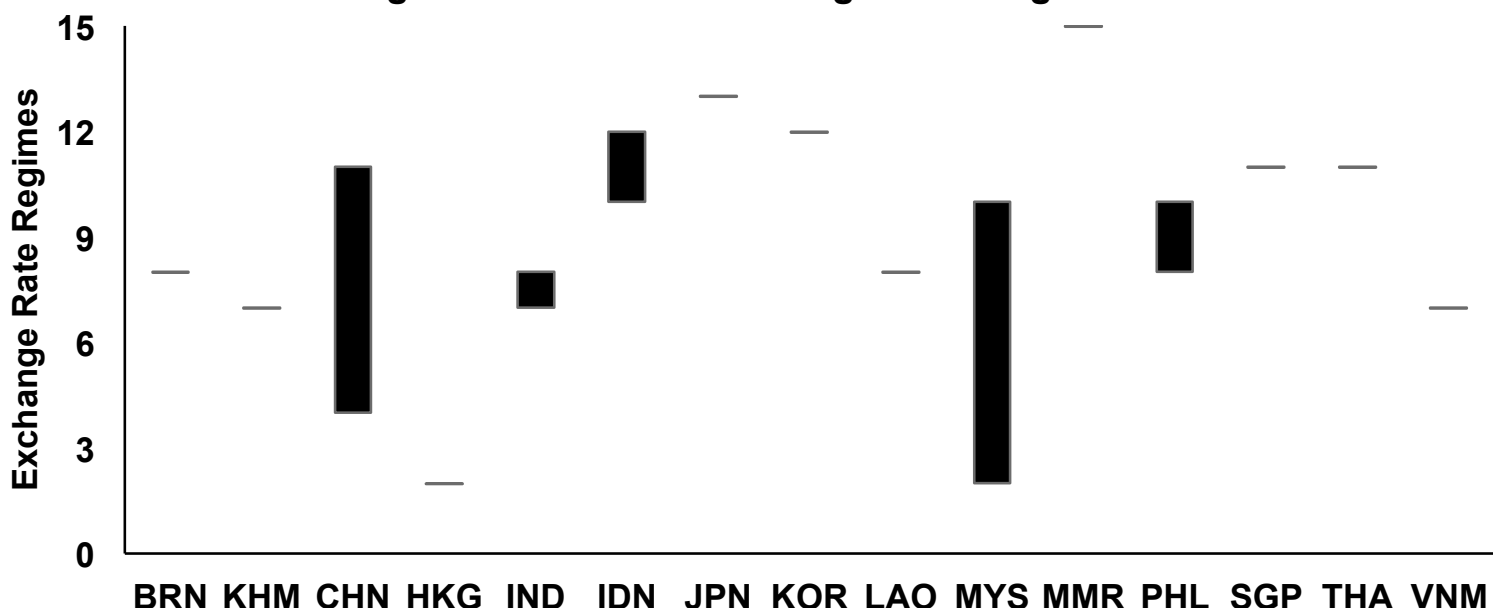

Note: 1: No separate legal tender; 2: Pre-announced peg or currency board arrangement; 3: Pre announced horizontal band that is narrower than or equal to $\pm 2 \%$; 4 : De facto peg; 5 : Pre announced crawling peg; 6 : Pre announced crawling band that is narrower than or equal to $\pm 2 \%$; 7 : De facto crawling; 8: De facto crawling band that is narrower than or equal to $\pm 2 \%$; 9 : Pre announced crawling band that is wider than or equal to $\pm 2 \%$; 10 : De facto crawling band that is narrower than or equal to $\pm 5 \%$; 11 : Moving band that is narrower than or equal to $\pm 2 \%$; 12 : Managed floating; 13 : Freely floating; 14: Freely falling; 15: Dual market in which parallel market data is missing.

Source: Reinhart and Rogoff (2004) 
These databases, though quite useful for many analyses, have limited success in measuring the finer structure of intermediate regimes. To identify these finer changes in exchange rate behavior and to investigate the extent of the individual currency's linkages with the three major global currencies: the US dollar, the Euro, and the Japanese Yen, we use the methodology outlined by Frankel and Wei (1994). Daily data of exchange rates are used to conduct regression of log differences of the local currency (in terms of the Swiss franc) on log differences of the three major currencies (in terms of the Swiss franc). The coefficients in Equation (8) can be interpreted as the extent to which the G3 currencies influence the individual currencies. The regression equation is as follows:

$$
\Delta \log \varepsilon_{i, t}^{C H F}=\alpha_{0}+\beta_{1} \Delta \log \varepsilon_{U S D, t}^{C H F}+\beta_{1} \Delta \log \varepsilon_{E U R, t}^{C H F}+\beta_{1} \Delta \log \varepsilon_{J P Y, t}^{C H F}+\mu_{i, t}
$$

where $\log \varepsilon_{i, t}^{C H F}$ is the value of currency i vis-à-vis the Swiss franc, and $\log \varepsilon_{U S D, t}^{C H F}, \log \varepsilon_{E U R, t}^{C H F}$ and $\log \varepsilon_{J P Y, t}^{C H F}$ are the values of the dollar, euro, and yen in terms of the Swiss franc. The coefficients are considered to represent the weights of the respective currencies. We look at the recursive least squares estimate from January 2001 to September 2011 to obtain dynamic coefficients. The recursive estimates are generated by running the above regression iteratively using a moving window of data by dropping old observations as new ones are added. Figure 9 plots the coefficients of the recursive estimates.

In the case of most currencies, the US Dollar exerts the greatest influence. The Chinese Yuan's case is the clearest with the Yuan being perfectly linked to the US Dollar from 2001 to the middle of 2005 and the coefficient being 1.00 prior to 2005 . The announcement in July 2005 to move to a currency basket peg was associated with a marginal decline in the linkage with the US Dollar and an increase in the linkage with the Japanese Yen. However, this was a short-term phenomenon and soon the linkage with the Dollar increased to be in excess of 0.98. Through most of the period the linkage of the Chinese Yuan with the Euro has been statistically insignificant. In contrast, the Malaysian Ringgit, which also delinked from the US dollar in July 2005, has shown a reduction in linkage with the Dollar. The linkage dropped below 0.8 towards end 2007, although after the global financial crisis there was an increase in the linkage till 2010. On the other hand, linkage with the Euro significantly increased in 2007 and has continued to be relatively high since then. Thus Malaysia seems to have made the successful transition from a US dollar peg to a currency basket peg. While the average adjusted R2 for the Chinese Yuan was in excess of 0.98, in the case of the Malaysian Ringgit it was around 0.88 .

The Philippine Peso continued to exhibit a strong linkage with the US Dollar, with the linkage varying between 0.73 and 1.01 between 2001 and 2005. This was higher than most other Asian economies, and in contrast to IMF's classification of the Peso as independently floating. There was an increase in its linkage with the Euro in 2007 but this declined sharply during the subsequent months. Moreover, the linkage was not always statistically significant. The Philippine Peso also exhibited intermittent increase in linkage with the Japanese Yen. The linkage between the Indian Rupee and the dollar exhibited a downtrend between 2001 and 2007. However, there was an increase in the degree of linkage prior to the collapse of Lehman Brothers and again through most of 2010. After 2007, there was an increase in the linkage with the Euro, but the there was a great deal of volatility in the extent of relationship, and it was not statistically significant across all periods. The extent of linkage between the Indian Rupee and the Japanese Yen has been relatively low and insignificant through most of the period. 
Figure 8: Recursive Least Square Estimates for Participating Currencies

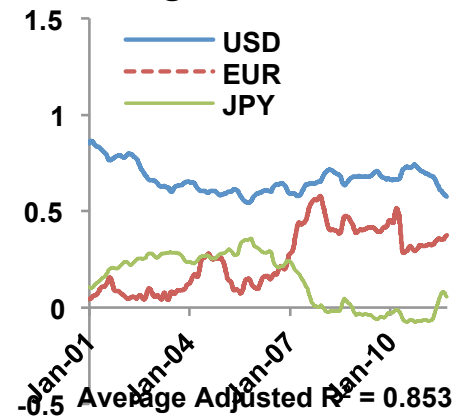

(a) Brunei Dollar

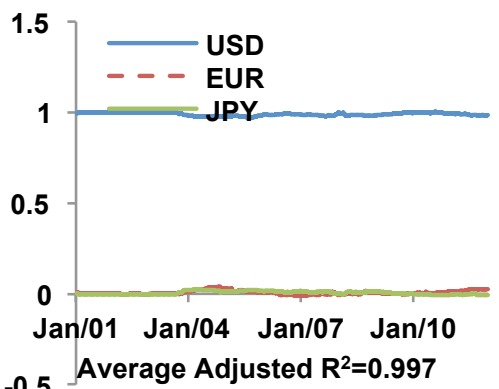

(d) Hong Kong Dollar

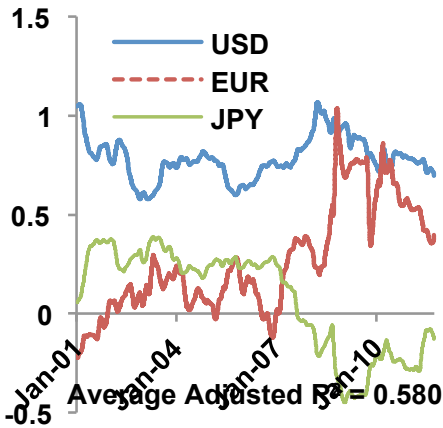

(g) Korean Won

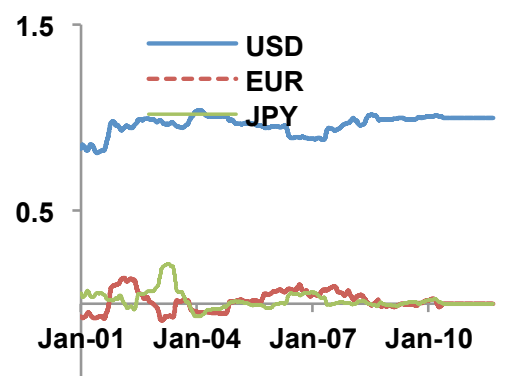

-0.5 Average Adjusted $\mathbf{R}^{2}=\mathbf{0 . 8 7 5}$ (j) Myanmar Kyat

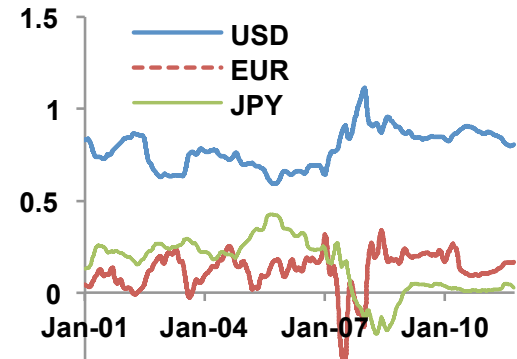

-0.5 Average Adjusted $R^{2}=0.512$

(m) Thai Baht

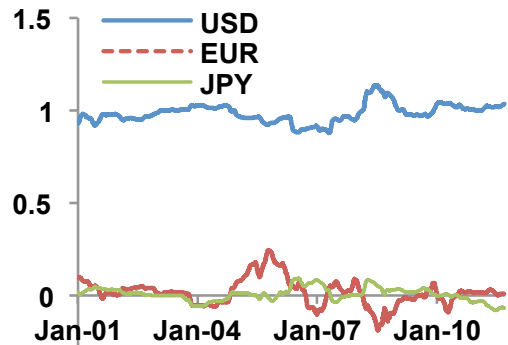

-0.5 Average Adjusted $R^{2}=0.791$

(b) Cambodian Riel

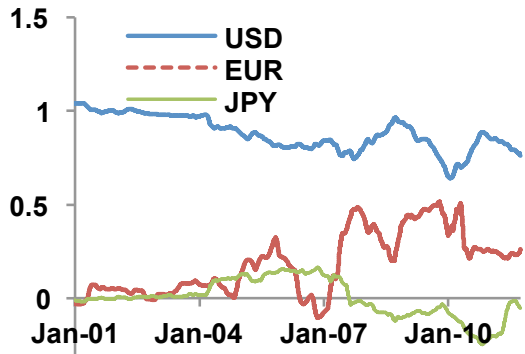

-0.5 Average Adjusted $R^{2}=0.793$

(e) Indian Rupee

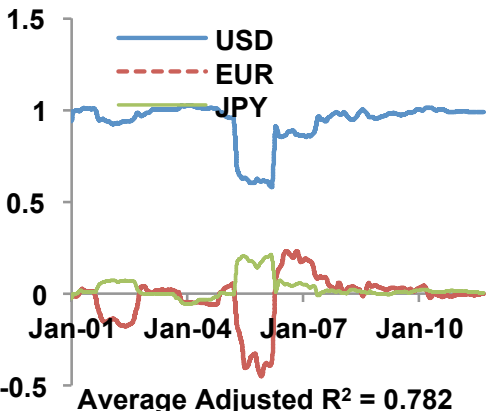

(h) Lao PDR Kip

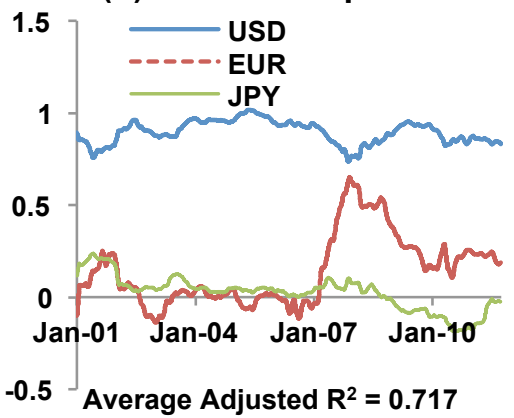

(k) Philippine Peso

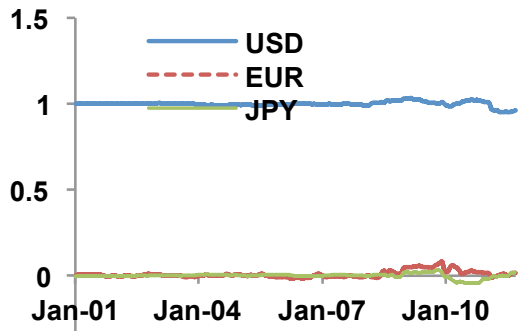

-0.5 Average Adjusted $\mathbf{R}^{2}=0.957$

(n) Viet Nam Dong

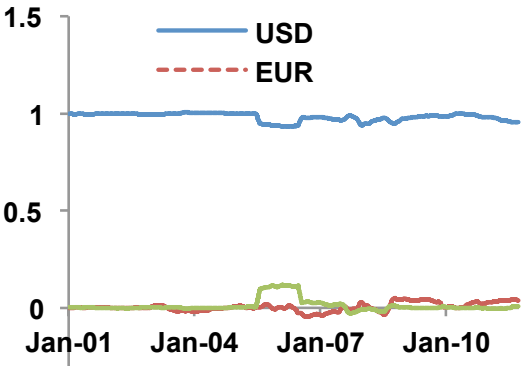

-0.5 Average Adjusted $R^{2}=0.984$

(c) PRC Yuan

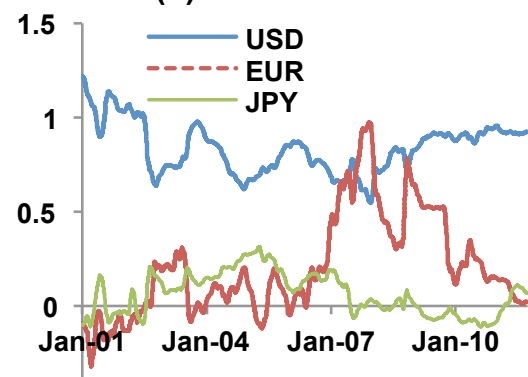

-0.5 Average Adjusted $R^{2}=0.465$

(f) Indonesian Rupiah

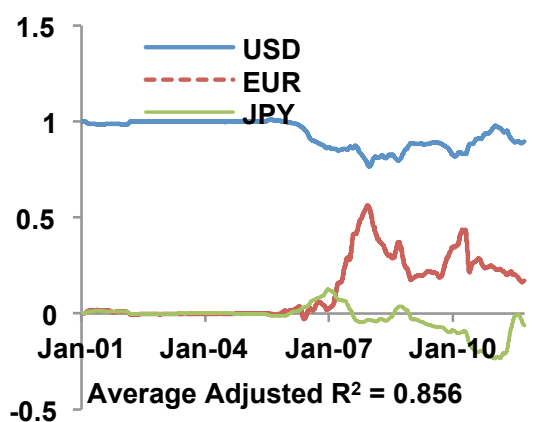

(i) Malaysian Ringgit

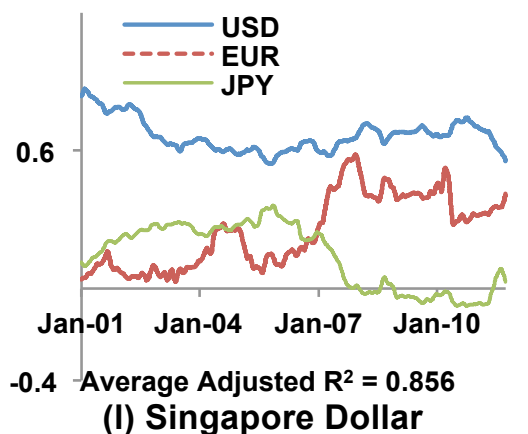

(I) Singapore Dollar

Source: Author's Estimates 
The extent of linkage of the Indonesian Rupiah and the Thai Baht with the US Dollar dropped from being over unity and around 0.8 respectively in 2001 to below 0.6 in 2007, after which there was some increase in the extent of linkage. While the Rupiah's linkage with the Euro increased sharply between 2006 and 2008 it stayed below 0.2 in case of the Baht. In both cases the relationship exhibited considerable volatility and was not always statistically significant. Moreover, in the case of the Rupiah, the extent of the linkage also dropped considerably since the global financial crisis, while with the Baht it remained relatively steady. In case of both the Baht and the Rupiah, the coefficient on the Japanese Yen increased between 2001 and 2005 but declined thereafter to be close to zero.

In the case of the Korean Won, the coefficients indicate the importance of other factors in the currency regime. The Won's linkage with the US Dollar exhibited a decreasing trend between 2001 and 2005 when it dropped to below 0.6 compared to 1.05 in 2001 . Subsequently, there was an increase in the linkage with the US Dollar, which again reversed after the onset of the global financial crisis. The linkage with the Japanese Yen hovered around 0.2 during 2001 to 2006 but has significantly declined since then, turning negative since mid-2007. Since 2007, there has been an increase in the linkage with the Euro, although the linkage was not significant for all the periods.

The Brunei Dollar is linked with the Singapore Dollar in a currency board arrangement and hence both these currencies exhibit similar movements against the major currencies. The Monetary Authority of Singapore targets a basket of currencies giving relatively higher weight to the US dollar. However, there has been a decline in the weight accorded to the US dollar between 2001 and 2006, after which there has been a moderate increase. On the other hand there has been a sharp increase in the linkage with the Euro, which has been offset by a decline in its linkage with the Japanese Yen.

Among the other ASEAN members, the Lao PDR Kip, the Cambodian Riel, and the Vietnamese Dong have been largely fixed to the US Dollar during 2001 to 2011. Almost across the entire period, the Euro and the Japanese Yen exerted an insignificant impact on the currencies of these countries.

While it is evident that by and large US Dollar is the currency is the currency that exerts the greatest influence across a number of Asian economies, the relationship between the individual Asian currencies and the G3 currencies is quite diverse. A number of Asian currencies remain fairly heavily managed, mostly against the US Dollar, presumably, to sustain export-led growth. Typically, the influence of the US Dollar is lower for the inflation targetters and floaters, as would be expected a priori.

\section{Conclusion}

Rising interdependence among Asian economies makes it important for these economies to strive for some form of exchange rate stability. In this paper, we evaluate the extent of exchange rate coordination among selected Asian economies by creating a hypothetical Asian Currency Unit. We find that Asian economies have exhibited little evidence of convergence of exchange rate movements. This can be explained by the diversity in the exchange rate regimes prevailing in these economies.

Given the diversity in exchange rate regimes, greater exchange rate coordination will require a high level of political commitment and willingness to subordinate domestic economic policies to defend the exchange rate arrangement. Moreover, this will have to be complemented with greater macroeconomic and fiscal coordination. The current European crisis highlights the dangers that advanced monetary integration brings in the face of 
economic and political divergences. Macroeconomic imbalances in a system of regional exchange rate coordination can create problems for all participating countries.

Greater exchange rate cooperation will also have to be complemented with a crisis prevention and resolution mechanisms. While the foundations for such mechanisms exist in institutions like the Chiang Mai Initiative Multilateralization (CMIM) and the ASEAN+3 Macroeconomic Research Office (AMRO), the resources available with these institutions need to be significantly beefed up. While the CMIM's reserve pool has been expanded to $\$ 240$ billion, it could prove inadequate if a full blown crisis was to occur in Asia. The other impediment is the contentious IMF link, a provision that allows member countries to draw only $30 \%$ of the agreed amounts without an IMF program. With the stigma that IMF still carries in the region, it would be hard for any country to adopt an IMF program. A recent example is that of Republic of Korea, which instead of resorting to the CMIM during the 2008 crisis, established a temporary reciprocal swap line of $\$ 30$ billion between Bank of Korea and Federal Reserve Bank.

AMROs role as an independent regional surveillance unit need to be significantly strengthened so as to be able to detect risks at the earliest and implement remedial actions swiftly. For this, significantly more resources need to be devoted to enable AMRO to undertake meaningful macroeconomic and financial market surveillance. AMRO should also collaborate with other international financial institutions to benefit from economies of scale. The surveillance process could be enhanced by the creation and monitoring of a regional currency unit by AMRO in line with the one described above. In a recent survey covering opinion leaders including government officials, academic, and bankers. Rana et al. (2012) found that over two-thirds of the respondents felt that the AMRO should calculate a regional currency unit and use it for regional surveillance, its key activity.

Thus it is evident that the Asian economies have a long way to go to achieve greater degree of exchange rate coordination. The recent events in Europe have illustrated the dangers of hastening into monetary integration without internal adjustments in some of the participating countries. Macroeconomic imbalances in any kind of a coordinated system will give rise to economic tensions. Thus Asian economies should proceed gradually towards exchange rate coordination on a path that will allow for greater flexibility and room for adjustment. 


\section{References}

Amsler, Christine and Lee, Junsoo, (1995) "An LM Test for a Unit Root in the Presence of a Structural Change," Econometric Theory, 11(02), pp. 359-368

Eichengreen, Barry (2006), "The Parallel Currency Approach to Asian Monetary Integration", American Economic Review, 96 (2), pp. 432-436.

Carrion-i-Silvestre, Josep Lluis, Del Barrio-Castro, Tomes. and Lopez-Bazo, Enrique (2005) "Breaking the Panels: An Application to the GDP Per Capita", Econometrics Journal, 8(2), pp 159-175.

Fan, C. Simon, and Wei, Xiangdong (2006), "The Law of One Price: Evidence from the Transitional Economy of China", The Review of Economics and Statistics, 88 (4), pp. 682697.

Frankel, Jeffrey A., and Wei, Shang-Jin (1994), "Yen Bloc or Dollar Bloc? Exchange Rate Policies of the East Asian Economies", in Macroeconomic Linkages: Savings, Exchange Rates, and Capital Flows, NBER-EASE Volume 3, (editors) Takatoshi Ito, and Anne O. Krueger, University of Chicago Press, pp. 295-333.

Girardin, Eric, and Steinherr, Alfred (2008), "Regional Monetary Units for East Asia: Lessons from Europe", ADBI Discussion Paper No: 116.

Im, Kyung So, Pesaran, M. Hashem, and Shin, Yongcheol (2003), "Testing for Unit roots in Heterogeneous Panels", Journal of Econometrics, 113 (1), pp. 53-74.

IMF (2007), "Evolution of Trade in Emerging Asia. Regional Economic Outlook: Asia and Pacific", International Monetary Fund, Washington DC.

IMF (2009), "De Facto Classi_cation of Exchange Rate Regimes and Monetary Policy Frameworks", International Monetary Fund, Washington DC.

Kawai, Masahiro, and Takagi, Shinji (2005), "Towards Regional Monetary Cooperation in East Asia: Lessons from Other Parts of the World", International Journal of Finance \& Economics, 10 (2), pp. 97-116.

Kuroda, Haruhiko, and Kawai, Masahiro (2002), "Strengthening Regional Financial Cooperation in East Asia", Asia Pacific Economic Papers No. 332, Australia-Japan Research Centre, Crawford School, Australian National University.

Levin, Andrew, Lin, Chien-Fu, and James Chu, Chia-Shang (2002), "Unit Root Tests in Panel Data: Asymptotic and Finite-sample Properties", Journal of Econometrics, 108 (1), pp. $1-24$.

Levy-Yeyati, Eduardo, and Sturzenegger, Federico (2005), "Classifying Exchange Rate Regimes: Deeds vs. Words", European Economic Review, 49 (6), p. 6.

Ogawa, Eiji, and Shimizu, Junko (2005), "A Deviation Measurement for Coordinated Exchange Rate Policies in East Asia", Research Institute of Economy, Trade and Industry Discussion paper No. 05017.

Ogawa, Eiji, and Shimizu, Junko (2007), "Progress toward a Common Currency Basket System in East Asia", Research Institute of Economy, Trade and Industry Discussion paper No. 07002. 
Ogawa, Eiji, and Yoshimi, Taiyo (2008), "Widening Deviation among East Asian Currencies", Research Institute of Economy, Trade and Industry Discussion paper No. 08010.

Ogawa, Eiji, and Yoshimi, Taiyo (2009), "Analysis on $\beta$ and $\sigma$ Convergences of East Asian Currencies", Research Institute of Economy, Trade and Industry Discussion paper No. 09-E018.

Rana, Pradumna Bickram, Chia, Wai-Mun, and Jinjarak, Yothin (2012), "Monetary Integration in ASEAN+3: A Perception Survey of Opinion Leaders", Journal of Asian Economics, 23 (1), pp. 1-12.

Reinhart, Carmen M., and Rogoff, Kenneth S. (2004), "The Modern History of Exchange Rate Arrangements: A Reinterpretation", The Quarterly Journal of Economics, 119 (1), pp. 148.

Wyplosz, Charles (2010), "An Asian Monetary Unit?", in The Future Global Reserve System An Asian Perspective, (editors) Jeffrey D. Sachs, Masahiro Kawai, Jong-Wha Lee, and Wing Thye Woo, Asian Development Bank. 